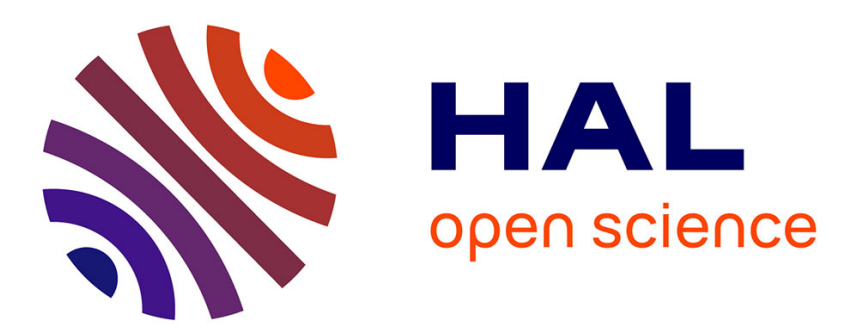

\title{
Isentropic modeling of a cirrus cloud event observed in the midlatitude upper troposphere and lower stratosphere
}

\author{
Nadège Montoux, Philippe Keckhut, Alain Hauchecorne, Julien Jumelet, \\ Hélène Brogniez, Christine David
}

\section{To cite this version:}

Nadège Montoux, Philippe Keckhut, Alain Hauchecorne, Julien Jumelet, Hélène Brogniez, et al.. Isentropic modeling of a cirrus cloud event observed in the midlatitude upper troposphere and lower stratosphere. Journal of Geophysical Research: Atmospheres, 2010, 115 (D2), pp.D02202. 10.1029/2009JD011981 . hal-00448611

\section{HAL Id: hal-00448611 \\ https://hal.science/hal-00448611}

Submitted on 2 Mar 2016

HAL is a multi-disciplinary open access archive for the deposit and dissemination of scientific research documents, whether they are published or not. The documents may come from teaching and research institutions in France or abroad, or from public or private research centers.
L'archive ouverte pluridisciplinaire HAL, est destinée au dépôt et à la diffusion de documents scientifiques de niveau recherche, publiés ou non, émanant des établissements d'enseignement et de recherche français ou étrangers, des laboratoires publics ou privés. 


\title{
Isentropic modeling of a cirrus cloud event observed in the midlatitude upper troposphere and lower stratosphere
}

\author{
N. Montoux, ${ }^{1}$ P. Keckhut, ${ }^{1}$ A. Hauchecorne, ${ }^{1}$ J. Jumelet, ${ }^{1}$ H. Brogniez, ${ }^{1}$ and C. David ${ }^{1}$ \\ Received 27 February 2009; revised 27 August 2009; accepted 11 September 2009; published 19 January 2010.
}

[1] This publication provides a detailed study of one cirrus cloud observed by lidar at the Observatory of Haute-Provence $\left(\sim 44^{\circ} \mathrm{N}\right)$ in January 2006 in the vicinity of the tropopause $(12-14 \mathrm{~km} / \sim 136-190 \mathrm{hPa} / 328-355 \mathrm{~K})$. The higher part of the air mass observed comes from the wet subtropics while the lower part comes from the midlatitudes. Both are advected by the Azores anticyclone, encounter cold temperatures ( 205 K) above the North Atlantic Ocean, and flow eastward along the anticyclonic flank of the polar jet stream. A simulation of this cloud by an isentropic model is tested to see if synoptic-scale atmospheric structures could explain by itself the presence of such clouds. The developments made in the Modélisation Isentrope du transport Méso-échelle de l'Ozone Stratosphérique par Advection (MIMOSA) model to take into account the three phases of water and their interactions allow reproduction of the occurrence of the cirrus and its temporal evolution. MIMOSA- $\mathrm{H}_{2} \mathrm{O}$ reproduces the atmospheric water vapor structures observed with Atmospheric Infrared Sounder (AIRS) with, however, an apparent wet bias of around 50\%. Reliable water vapor fields appear to be the main condition to correctly simulate such cirrus clouds. The model reproduces the cirrus cloud altitude for fall speeds around $1 \mathrm{~cm} / \mathrm{s}$ and gives ice water content around $3-4 \mathrm{mg} / \mathrm{m}^{3}$. Fall speed is also a critical parameter, and a better parameterization with altitude or other atmospheric conditions in the modeling of such cirrus clouds is required. This study also shows that supersaturation threshold impacts strongly the vertical and horizontal extension of the cirrus cloud but more slightly the ice water path.

Citation: Montoux, N., P. Keckhut, A. Hauchecorne, J. Jumelet, H. Brogniez, and C. David (2010), Isentropic modeling of a cirrus cloud event observed in the midlatitude upper troposphere and lower stratosphere, J. Geophys. Res., 115, D02202, doi:10.1029/2009JD011981.

\section{Introduction}

[2] Cirrus clouds cover about $30 \%$ of the globe [Wylie et al., 1994] and could have a frequency of occurrence of up to $50 \%$ at midlatitudes above France [Goldfarb et al., 2001]. They can be separated into three categories depending on their visible optical depth $\tau$ : the subvisual cirrus clouds with $\tau \leq 0.03$, the thin cirrus clouds with $0.03<\tau \leq 0.3$ and the opaque cirrus clouds with $0.3<\tau \leq 3$ [Sassen and Cho, 1992]. Their impact on the radiative balance of the Earth's atmosphere is significant [Baran and Francis, 2004; Mace et al., 2006; Fusina et al., 2007; Edwards et al., 2007] but numerous uncertainties remain about their influence in climate studies [Stephens et al., 1990]. To determine quantitatively their influence, a better knowledge of cirrus cloud formation processes, cloud frequencies [Zhang et al., 2005] and microphysics is necessary. When recent studies focus on microphysical processes inside cirrus clouds with bin microphysical models [Comstock et al., 2008; Kärcher, 2003;

\footnotetext{
${ }^{1}$ Laboratoire Atmosphères Milieux Observations Spatiales, UPMC, CNRS, Paris, France.

Copyright 2010 by the American Geophysical Union. 0148-0227/10/2009JD011981\$09.00
}

Reichardt et al., 2008 and Lin et al., 2005], it would be interesting to see how the synoptic-scale processes are important in the cirrus cloud formation.

[3] Among the cirrus clouds observed by lidar at midlatitudes above the Observatory of Haute-Provence in France (OHP: $\left.43.93^{\circ} \mathrm{N}, 5.71^{\circ} \mathrm{E}\right), 35 \%$ are optically thin cirrus clouds with the smallest estimated optical depth observed above $\mathrm{OHP}$, around $0.13 \pm 0.1$. These clouds are localized in average above the tropopause, at potential temperatures $(\theta)$ warmer by $7 \pm 16 \mathrm{~K}$ compared to the tropopause potential temperatures encountered [Keckhut et al., 2006]. They seem to be formed inside filaments of wet air coming from the tropics according to potential vorticity (PV) isentropic simulation [Keckhut et al., 2005]. The aim of this study is thus to test if a simple isentropic approach allowing reproducing the atmospheric synoptic-scale variability could reproduce the occurrence of this type of cirrus clouds. For this purpose, a case has been selected by lidar above OHP during the night of 18 to 19 January 2006.

[4] The global high-resolution (three grid points per degree in latitude and longitude) semi-Lagrangian MIMOSA (Modélisation Isentrope du transport Méso-échelle de l'Ozone Stratosphérique par Advection) model [Hauchecorne et al., 2002] advects potential vorticity on isentropic surfaces. It has 


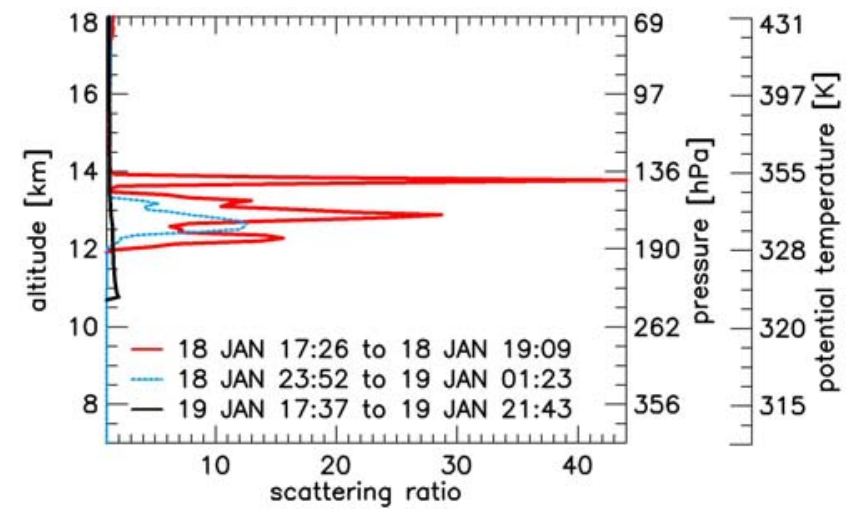

Figure 1. The $532 \mathrm{~nm}$ lidar scattering ratio as a function of altitude measured at the Observatory of Haute-Provence during two successive nights of January 2006. Pressure and potential temperature scales have been determined with the data from the Nîmes radiosounding recorded on 19 January 2006 at $0000 \mathrm{UTC}$.

been widely used to simulate the meridional transport of ozone from the polar stratospheric vortex by formation of filaments or the intrusion of tropospheric subtropical air in the midlatitude lower stratosphere observed by airborne and ground-based ozone lidars [Heese et al., 2001; Godin et al., 2002; Semane et al., 2006]. Concerning the water vapor distribution, MIMOSA has been successfully used to understand the origin of the structures observed in the water vapor mixing ratio profiles recorded by balloon-borne instruments [Durry et al., 2002; Durry and Hauchecorne, 2005]. MIMOSA has notably allowed identification of the tropical origin of air sounded between 16 and $23 \mathrm{~km}$ at midlatitudes [Durry et al., 2002]. But until now, only the potential vorticity field indicator of the air mass origin (stratospheric or tropospheric) was used in these studies. In the present work, it is necessary to add the water vapor and ice field to test if the model is able to reproduce the cirrus cloud observed. To insure interactions between the two phases through freezing and sublimation processes, a basic microphysical module is included in the MIMOSA model. As supersaturation conditions in the atmosphere are reported in many observations [Gierens et al., 2000; Ovarlez et al., 2002; Jensen et al., 2005], the model allows selection of supersaturation levels for cloud formation, and includes a coupling of the different isentropic levels through sedimentation of the ice particles formed at each grid point.

[5] In section 2, the cirrus case observed with lidar in January 2006 above OHP in the vicinity of the tropopause is described. The context in which it is formed is documented with back trajectories, and ancillary data, such as satellite water vapor data from Atmospheric Infrared Sounder (AIRS) and European Centre of Medium-range Weather Forecasts (ECMWF) analysis. In section 3, the MIMOSA model and the new developments made for this case study are presented as well as the method to initialize the water vapor field. Section 4 provides the results of the modeling with the evaluation of the modeled water vapor field and cirrus cloud altitude. Sensitivity tests on the influence of the fall speed and supersaturation threshold on the cirrus cloud characteristics are also conducted in section 4 to identify the largest source of uncertainties. Conclusions and discussions of the results are provided in section 5 .

\section{Description of the Case Study}

[6] An air tongue coming from the Gulf of Mexico on January 2006 has been observed a few days later above France with lidar showing the presence of a cirrus cloud around the tropopause. This case is very similar to a previous one already described by Keckhut et al. [2005] but is further documented with more available observations and appears to be a good candidate to better investigate the origin and formation processes of such cirrus clouds located in the vicinity of the tropopause. Back trajectory isentropic calculations show that air masses were transported from the subtropical latitudes and midlatitudes by the Azores anticyclone. Global water vapor field indicates that air is wetter (20 ppmv) than usual midlatitude conditions. Radiosounding and ECMWF analysis show that cold enough temperatures $(200-215 \mathrm{~K})$ were encountered to form a cirrus cloud.

\subsection{Cirrus Evolution Above OHP}

[7] The case selected for this study is a cirrus cloud observed by the $532 \mathrm{~nm}$ aerosol lidar at OHP $\left(43.93^{\circ} \mathrm{N}\right.$, $5.71^{\circ} \mathrm{E}$ ) during the night of 18 to 19 January 2006 between 12 and $14 \mathrm{~km}$ (Figure 1). The vertical resolution of the lidar measurements is $75 \mathrm{~m}$. The following night, where no cloud was observed, is taken as reference in this study (Figure 1). According to the radiosounding launched at Nîmes $(105 \mathrm{~km}$ away from OHP) by Météo-France on 19 January 2006 at 0000 UTC, the pressures at the cloud top and bottom altitudes are 136 and $190 \mathrm{hPa}$, respectively, and the temperature at the cloud altitudes ranges between 201 and $207 \mathrm{~K}$. The corresponding potential temperatures vary between 328 and $355 \mathrm{~K}$. Satellite observations provided by the $10.5-12.5 \mu \mathrm{m}$ channel of the Advanced Very High Resolution Radiometer (AVHRR) on board the NOAA-17 and 18 platforms confirm the presence of a cloud eastward of the observatory at 2158 UTC on 18 January and at 0223 UTC on 19 January. As shown on Figure 1, during the night, the cirrus cloud top altitude decreases from $14 \mathrm{~km}$ down to $13.5 \mathrm{~km}$.

\subsection{Back Trajectory Investigations}

[8] To determine the position of the cirrus cloud observed at OHP relative to the tropopause, a modeling of the PV field with the MIMOSA model [Hauchecorne et al., 2002] has been made with an initialization on 15 January 2006 at 0000 UTC on 54 isentropic surfaces between 320 and $450 \mathrm{~K}$. The vertical sampling is thus around $100 \mathrm{~m}$ near the tropopause. A detailed description of the MIMOSA model will be provided in section 3 . The dynamical tropopause can be defined by a constant potential vorticity surface, and values taken between 1 and 3.5 pvu have been shown to be suitable [Bithell and Gray, 1997]. In this study, the 2.5 pvu surface has been selected and corresponds approximately to the minimum value of effective diffusivity at $350 \mathrm{~K}$ according to Haynes and Shuckburgh [2000]. On 18 January 2006 at 1800 UTC the dynamical tropopause is thus at $13.0 \pm 0.1 \mathrm{~km}$ ( $345 \mathrm{~K})$, moving to $12.3 \pm 0.1 \mathrm{~km}(335 \mathrm{~K})$ on 19 January 2006 at 0000 UTC. By comparison, the tropopause defined by the gradient of temperature is around $13.5 \mathrm{~km}$ on 19 January 2006 at 0000 UTC according to the Nîmes radiosounding. 


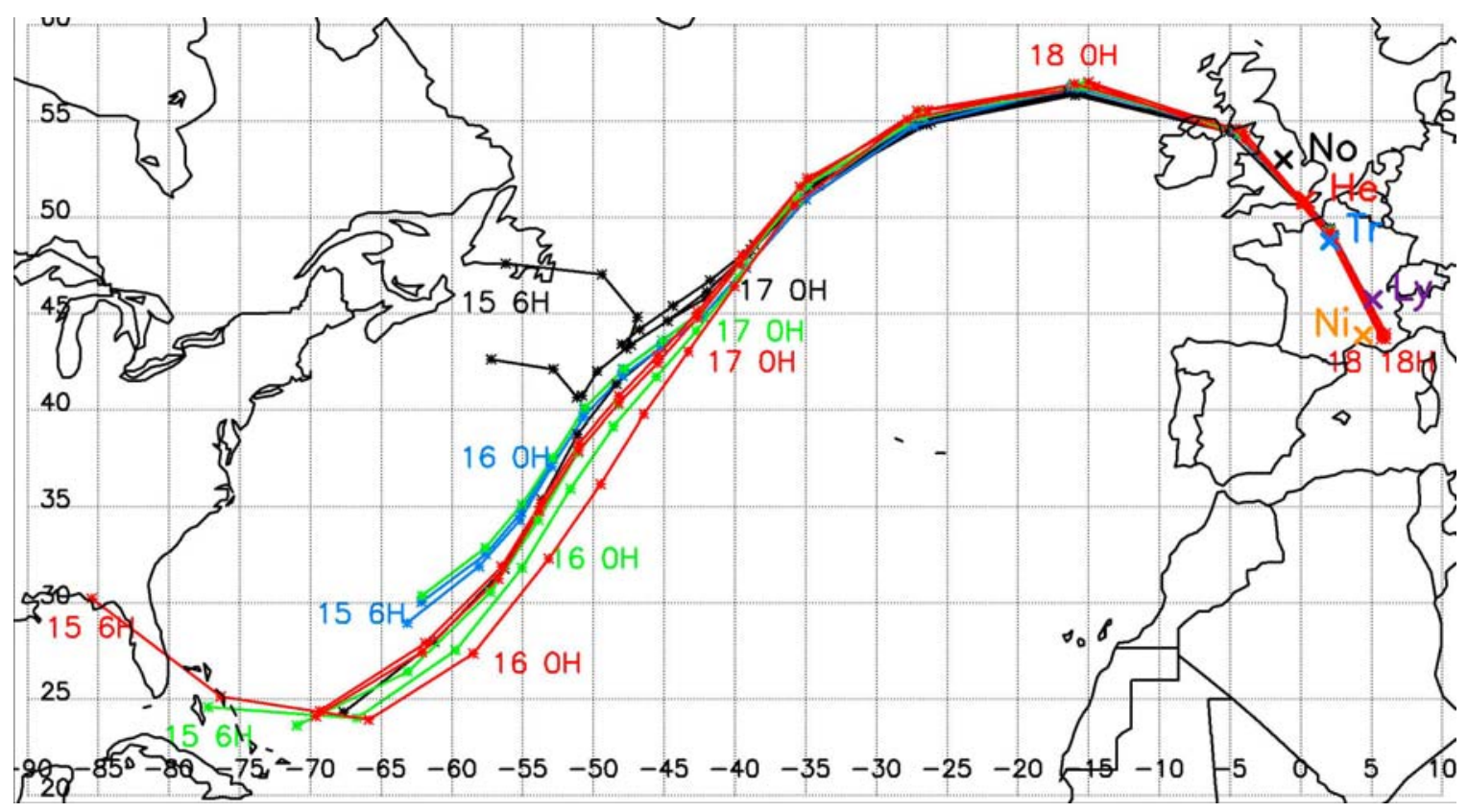

Figure 2. Back trajectories of the four grid points around $\mathrm{OHP}\left(43.67^{\circ} \mathrm{N} / 5.67^{\circ} \mathrm{E}, 43.67^{\circ} \mathrm{N} / 6^{\circ} \mathrm{E}, 44^{\circ} \mathrm{N} /\right.$ $5.67^{\circ} \mathrm{E}$, and $44^{\circ} \mathrm{N} / 6^{\circ} \mathrm{E}$ ) initialized 18 January 2006 at 1800 UTC until 15 January 2006 at 0600 UTC for the $340 \mathrm{~K}$ (black), $341 \mathrm{~K}$ (blue), $342 \mathrm{~K}$ (green), and $343 \mathrm{~K}$ (red) isentropic levels in the middle of the cirrus cloud observed by lidar at OHP. Some dates have been written along the trajectories of the nearest grip point from $\mathrm{OHP}\left(44^{\circ} \mathrm{N} / 5.67^{\circ} \mathrm{E}\right)$. Crosses denote radio-sounding stations: Nottingham $\left(53^{\circ} \mathrm{N} / 1.25^{\circ} \mathrm{W}\right.$ in black), Herstmonceux $\left(50.9^{\circ} \mathrm{N} / 0.32^{\circ} \mathrm{E}\right.$ in red), Trappes $\left(48.77^{\circ} \mathrm{N} / 2.02^{\circ} \mathrm{E}\right.$ in blue), Lyon $\left(45.73^{\circ} \mathrm{N} /\right.$ $5.08^{\circ} \mathrm{E}$ in purple), and Nîmes $\left(43.87^{\circ} \mathrm{N} / 4.4^{\circ} \mathrm{E}\right.$ in orange).

The cirrus cloud is thus partly in the upper troposphere and partly in the lower stratosphere.

[9] Four-day back trajectories have been computed for the levels between $336 \mathrm{~K}$ and $348 \mathrm{~K}$ at $1 \mathrm{~K}$ resolution by using a succession of 6 hourly simulations and results for the $340,341,342$ and $343 \mathrm{~K}$ isentropic levels are shown in Figure 2. For consistency, four grid points located around OHP were considered. The air mass sampled by the OHP lidar (Figure 2) comes from two different locations. For the lower part $(\theta \leq 340 \mathrm{~K})$, the air mass is originating in the midlatitudes, while for the higher part $(\theta \geq 342 \mathrm{~K})$ the air mass comes from the subtropics, between $24^{\circ} \mathrm{N}$ and $30^{\circ} \mathrm{N}$ on 15 January 2006 at 0600 UTC.

\subsection{Description of the Water Vapor Field}

[10] AIRS is an instrument providing water vapor mixing ratio fields at high horizontal resolution. In this section, AIRS allows thus to describe the water vapor field associated with the cirrus cloud formation. In addition, in section 4.1, AIRS will be used to evaluate the synoptic structures of the modeled water vapor field.

\subsubsection{Description of the AIRS Instrument}

[11] AIRS is a cross-track nadir scanning sounder launched on 4 May 2002 on board the EOS (Earth Observing System) Aqua satellite. The channels used for the water vapor retrievals are in the ranges $6.23-7.63 \mu \mathrm{m}$ and 3.63-3.83 $\mu \mathrm{m}$. AIRS combined with Advanced Microwave Sounding Unit A (AMSU-A), a microwave temperature sounder also aboard the Aqua spacecraft, provides a single "cloud-clear" infrared spectrum [Aumann et al., 2003]. The water vapor profiles are then obtained over footprints of $45 \mathrm{~km} \times 45 \mathrm{~km}$ with a horizontal resolution of $50 \mathrm{~km}$, similar to the MIMOSA horizontal sampling (around $37 \mathrm{~km}$ in latitude and longitude near the equator). The data used in this study are from the version 5 retrieval (see http://mirador.gsfc.nasa.gov/cgi-bin/mirador/ presentNavigation. pl?tree $=$ project\&project $=$ AIRS $)$. Comparisons between AIRS version 4 and Aura-MLS (Microwave Limb Sounder) version 2.2 water vapor data have demonstrated reliable measurements up to $200 \mathrm{hPa}$ for AIRS when excluding the coincidences with MLS water vapor amounts less than 20 ppmv where AIRS loses sensitivity [Read et al., 2007]. Indeed, in the stratosphere and around the tropopause, AIRS water vapor mixing ratios are more than $50 \%$ greater than MLS. Between 316 and $178 \mathrm{hPa}$, AIRS shows only a small wet bias of $6 \%$ compared to MLS for mixing ratios ranging between 30 and $100 \mathrm{ppmv}$ and even a better agreement for mixing ratios ranging between 100 and 500 ppmv. In contrast, comparisons with different types of water vapor radiosondes from the RAOB stations for pressure less than $300 \mathrm{hPa}$ reveal a $10 \%$ dry bias in the AIRS version 4 water vapor data. However, this bias is comparable to the absolute accuracy of the sondes [Tobin et al., 2006; Divakarla et al., 2006]. Concerning the v5 retrieval, first comparisons made over the tropics [Montoux et al., 2009] seem to indicate that the new version is a little drier than the previous one especially for the pressures less than $100 \mathrm{hPa}$. However, further comparisons will be necessary to make a complete evaluation of the AIRS v5 water vapor data.

\subsubsection{AIRS Observations}

[12] Figure 3 shows the water vapor mixing ratios measured by AIRS on 16 January 2006 from 0600 to 1800 UTC in the 150-200 hPa pressure layer. AIRS has a limited sensitivity in this layer because of the influence of the water 


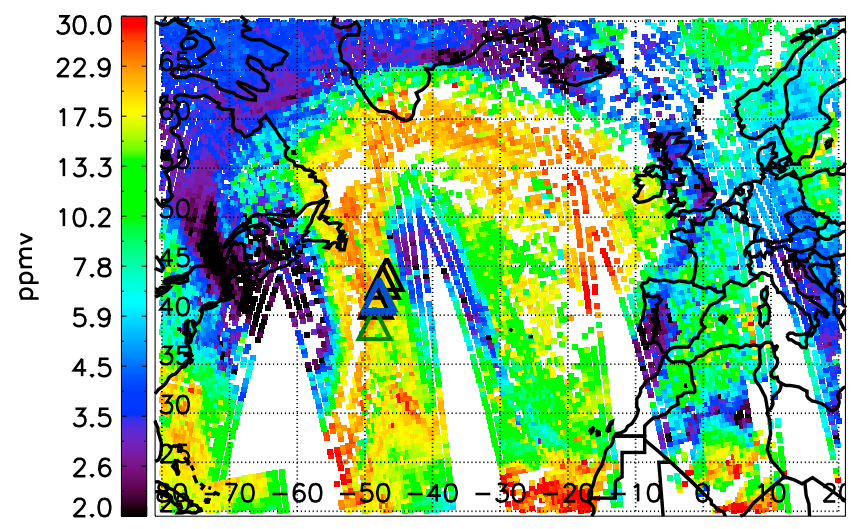

Figure 3. AIRS water vapor mixing ratios measured on 16 January 2006 from 0600 to 1800 UTC in the 150-200 pressure layer. Triangles indicate the locations of the computed $340 \mathrm{~K}$ (black), $341 \mathrm{~K}$ (blue), and $342 \mathrm{~K}$ (green) $(\sim 185 / 194 \mathrm{hPa})$ back trajectories on 16 January 2006 at 1200 UTC.

content from underlying layers. However, the air mass associated with the top of the cirrus cloud, coming from the subtropical troposphere, appears moister than the surrounding air.

\subsection{Description of the Temperature and Dynamics}

[13] Figures 4a and 4c show the geopotential altitude and the horizontal wind intensity, respectively, on 16 January 2006 at $1200 \mathrm{UTC}$ on the $200 \mathrm{hPa}$ surface provided by the ECMWF analysis (ISF model, cycle 29r2). Figures 4a and $4 \mathrm{c}$ are almost identical for the $150 \mathrm{hPa}$ surface. The trajectory of the air masses is influenced by the Azores anticyclone (Figure 4a), and air masses move along the anticyclonic flank of the polar jet stream (Figure 4c). The conditions are quite similar to those described in the study by Sassen et al. [1989] where an extensive upper level cirrus system was located above Wisconsin on the anticyclonic shear side of the jet axis. In our case, in the anticyclonic zone, the temperature is cold enough (between 200 and $215 \mathrm{~K}$ ) to reach the ice saturation level and thus allow the formation of ice crystals. This can be seen on Figure $4 \mathrm{~b}$ showing the temperature field on the $200 \mathrm{hPa}$ surface on 16 January 2006 at 1200 UTC.

[14] To have a realistic isentropic modeling, the diabatic processes must be negligible; that is, the cross-isentropic transport is negligible. To test if this is the case, 3-D back trajectories computed from a 3-D advection-condensation

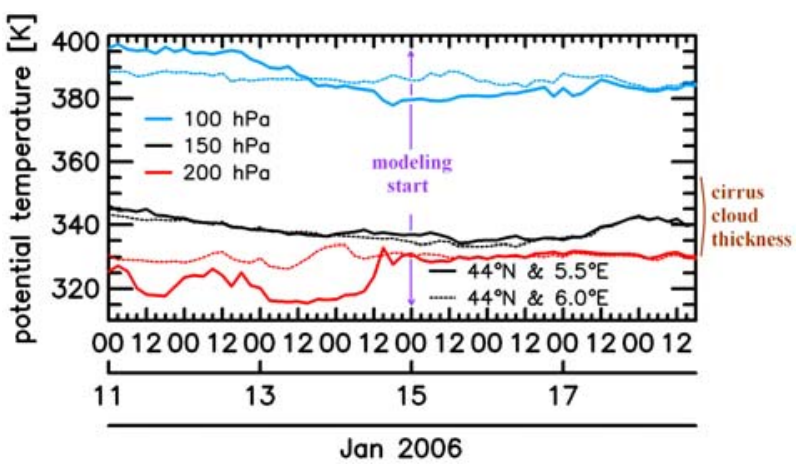

Figure 5. Evolution of the potential temperature between 10 January 2006 at 1800 UTC and 18 January 2006 at 1800 UTC obtained from back trajectories for different locations close to OHP (solid and dotted lines) and some altitudes (i.e., pressures: $100 \mathrm{hPa}$ (blue), $150 \mathrm{hPa}$ (black), and $200 \mathrm{hPa}$ (red)).

Lagrangian model [Pierrehumbert, 1998; Pierrehumbert and Roca, 1998] have been performed. The back trajectories have been calculated using the temperature and wind fields provided by ECMWF from the initial horizontal $1.125^{\circ}$ grid down to a $0.5^{\circ}$ regular grid. Forecasts $(0300,0900,1500$ and 2100 UTC) and analyses (0000, 0600, 1200 and 1800 UTC) were combined together to improve the temporal resolution of $6 \mathrm{~h}$ down to $3 \mathrm{~h}$ [Legras et al., 2003; Stohl et al., 2004], and the air masses were launched up to 8 days backward in time. The evolution of the potential temperature along the 8 day back trajectories initialized on 18 January 2006 at 1800 UTC for the two points close to OHP $\left(44^{\circ} \mathrm{N} / 5.5^{\circ} \mathrm{E}\right.$ and $\left.44^{\circ} \mathrm{N} / 6^{\circ} \mathrm{E}\right)$ is depicted in Figure 5. For the common period of simulation from 15 to 18 January 2006, the MIMOSA 2-D back trajectories (Figure 2) and the advection-condensation Lagrangian 3-D back trajectories are in agreement in their latitudinal and longitudinal evolution. Concerning the evolution in altitude on the same period, the 3 -D back trajectories initialized at $200 \mathrm{hPa}$ (just below the bottom of the cirrus cloud at $190 \mathrm{hPa}$ ) reveal fluctuations in potential temperature of $\sim 3 \mathrm{~K}$ that can be due either to noise in the ECMWF fields or to inconsistencies between the forecasts and the analyses. On the other hand, during the same period, the 3-D back trajectories initialized at $150 \mathrm{hPa}$ (inside the cirrus cloud) show greater fluctuations in potential temperature of around $8 \mathrm{~K}$ (identical at $100 \mathrm{hPa}$, above the top of the cirrus cloud). However, these fluctuations are of lesser vertical extent than the cirrus
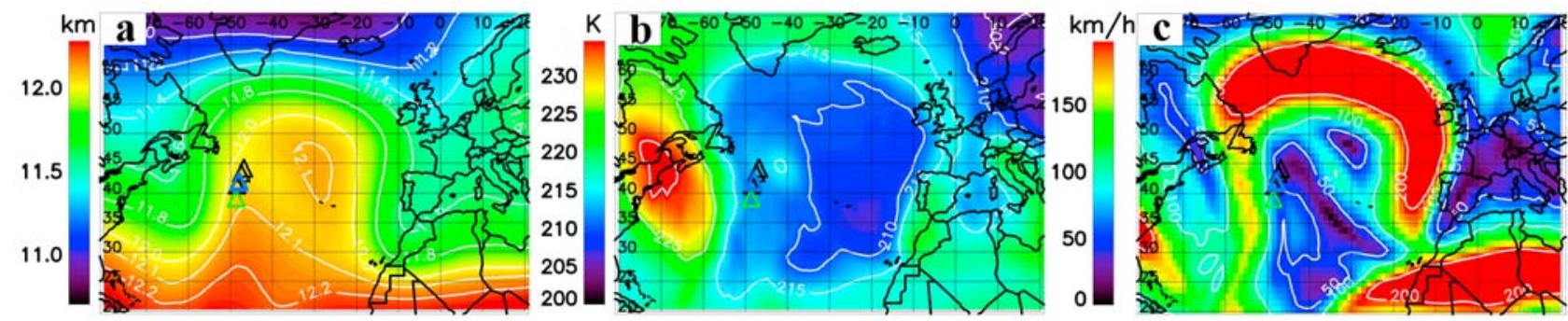

Figure 4. (a) Geopotential altitude, (b) temperature, and (c) horizontal wind intensity on 16 January 2006 at $1200 \mathrm{UTC}$ on the $200 \mathrm{hPa}$ pressure surface provided by the ECMWF analysis. Triangles indicate the locations of the computed $340 \mathrm{~K}$ (black), $341 \mathrm{~K}$ (blue), and $342 \mathrm{~K}$ (green) $(\sim 185 / 194 \mathrm{hPa}) \mathrm{back}$ trajectories on 16 January 2006 at 1200 UTC. 


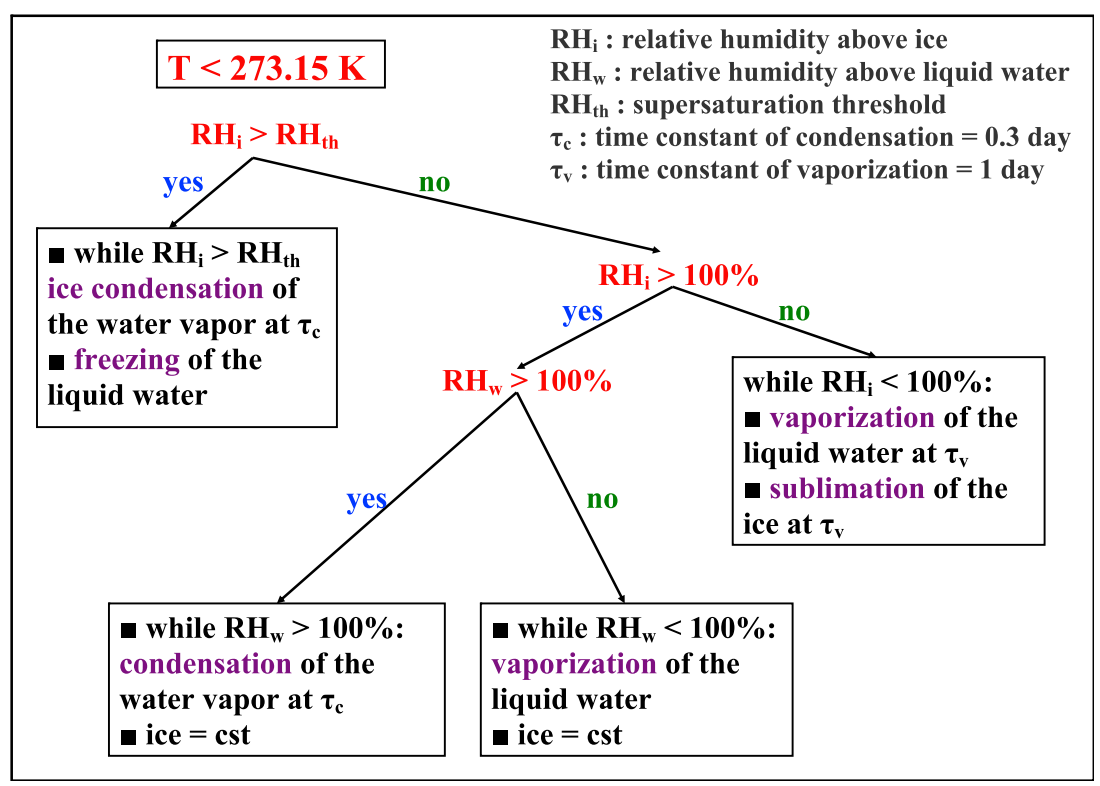

Figure 6. Diagram of the microphysical module implemented in the MIMOSA- $\mathrm{H}_{2} \mathrm{O}$ model.

cloud thickness itself and thus do not preclude the use of an isentropic model as MIMOSA to simulate this cirrus cloud.

\section{Description of the MIMOSA Model}

\subsection{Initial Model}

[15] The MIMOSA initial model is described in detail by Hauchecorne et al. [2002]. Its main characteristics are given below. Basically, the model advects the potential vorticity (PV) on several isentropic levels by horizontal wind components on an $x-y$ grid centered at the North Pole. On each isentropic surface higher than $320 \mathrm{~K}$, the initial field of $\mathrm{PV}$ is calculated by using the horizontal wind and temperature fields given on 17 pressure levels from 500 to $1 \mathrm{hPa}$ by the ECMWF analysis and the Holton [1992] definition of PV,

$$
\mathrm{PV}=-g \frac{\partial \theta}{\partial P}\left(\xi_{\theta}+f\right)
$$

where

$P$ pressure, $\mathrm{Pa}$;

$g$ gravitational constant, $\mathrm{m} \mathrm{s}^{-2}$;

$f$ Coriolis parameter, $\mathrm{s}^{-1}$;

$\theta$ potential temperature, $\mathrm{K}$;

$\xi_{\theta} \quad$ vertical component of the relative vorticity on an isentropic surface, $\mathrm{s}^{-1}$.

[16] Isentropic surfaces lower than $320 \mathrm{~K}$ intercept the ground at some locations (over mountains, for example) and, consequently, ECMWF temperature and wind are not available, and prevent correct initialization and advection of the PV field. The horizontal resolution of the MIMOSA model is around $0.33^{\circ}$ while the ECMWF analyses are taken at $1.125^{\circ}$. The initial field of PV is then advected by the 6 hourly ECMWF horizontal wind field analyses with a time step of $1 \mathrm{~h}$. To preserve the homogeneity of the field, a regridding of the PV field on the original orthogonal grid, centered at the North Pole and extending up to $10^{\circ}$ south, is made every $6 \mathrm{~h}$. The numerical horizontal diffusion led by this regridding has been estimated by Hauchecorne et al. [2002] to be about $1350 \mathrm{~m}^{2} \mathrm{~s}^{-1}$, close to the atmospheric diffusion estimated by Waugh et al. [1997] with tracer-tracer correlations $\left(1000 \mathrm{~m}^{2} \mathrm{~s}^{-1}\right)$. The diabatic evolution (especially the radiative contribution) of the PV field at large scales (greater than $300 \mathrm{~km}$ ) is taken into account by applying a relaxation toward the ECMWF PV field with a time constant of 10 days every $6 \mathrm{~h}$. The MIMOSA PV is not a true dynamical PV and is called "advected PV." It is well correlated with the concentration of long-lived species [Rao et al., 2003].

\subsection{New Developments in the MIMOSA Model}

[17] Water vapor is not a passive tracer like the advected PV [Hauchecorne et al., 2002] in the atmosphere. Water vapor can condensate into liquid water or ice depending on the pressure and temperature of the atmosphere and is also redistributed vertically through sedimentation effects. In the model, it is then necessary to represent the basic processes corresponding to the exchanges of water between their different phases. This is made through an additional microphysical module in the MIMOSA model which led to a new extension of the model called MIMOSA- $\mathrm{H}_{2} \mathrm{O}$.

\subsubsection{Microphysical Module}

[18] Several tracers for the different phases of water have been implemented. There are water vapor mixing ratio, liquid water mass concentration and ice mass concentration for the gas, liquid and ice phases, respectively. In the upper troposphere, even at midlatitudes, supersaturation with respect to ice occurs frequently [Gierens et al., 2000; Ovarlez et al., 2002; Jensen et al., 2005]. In the microphysical model, this is taken into account by imposing a supersaturation threshold required to condensate water vapor or supercooled water into ice. For the baseline simulations (sections 4.1 to 4.3 ), a threshold of $130 \%$ has been chosen corresponding to the mean supersaturation observed at northern midlatitudes during the Interhemispheric Difference in Cirrus Properties 
from Anthropogenic Emissions (INCA) campaign by Ström et al. [2003]. The influence of this threshold will be tested further in section 4.4. The condensation is obtained for the water vapor in excess compared to the supersaturation threshold with a time constant of 0.3 days [Gettelman et al., 2002]. Below the saturation with respect to ice, ice is evaporated with a time constant of 1 day [Gettelman et al., 2002]. Between the ice saturation and the supersaturation level specified to initiate ice formation, supercooled liquid water is formed or evaporated, depending on whether saturation with respect to liquid is achieved or not, with the same time constants that are used for ice. A diagram summarizing the phase changes in the module is given in Figure 6.

[19] This module includes a constant fall speed for the ice particles $\mathrm{V}_{\mathrm{s}}$, thus redistributing the water content between the different isentropic levels. For each isentropic level $i$, a fraction $F_{i}$ of ice water content, expressed in equation (2), is redistributed on the levels below assuming a homogenous distribution of the ice water content in the layer represented by the isentropic level $i$.

$$
F_{i}=\min \left(\frac{V_{s} \times \Delta t}{H_{i}}, 1\right)
$$

where

$V_{s}$ fall speed, $\mathrm{m} \mathrm{s}^{-1}$;

$\Delta t$ time step $(6 \mathrm{~h}), \mathrm{s}$;

$H_{i}$ height of the layer represented by the isentropic level $i, \mathrm{~m}$.

[20] Following Holton and Gettelman [2001], the fall speed is fixed at $4 \mathrm{~mm} / \mathrm{s}$ and corresponds to ice particles with radius close to $5 \mu \mathrm{m}$ [Boehm et al., 1999]. The effective radius of the ice particles corresponding to the fall speed selected is never used in the model. Several studies based on in situ measurements support the use of small radius/low fall speed for cold high cirrus clouds modeling: many observations summarized by Dowling and Radke [1990] indicated crystal length ranging from 1 to $8000 \mu \mathrm{m}$, while other studies showed that in the troposphere the observed crystal size generally decreases with the decrease of the temperature with height [Heymsfield and Iaquinta, 2000; Wang and Sassen, 2002; Deng and Mace, 2008] and that the fall speed increases with the crystal size [Heymsfield, 2003; Deng and Mace, 2008]. With cold temperatures $(\sim 200 \mathrm{~K})$ in this case, a small fall speed corresponding to small particles seems to be appropriate. Even if a recent study shows that the presence of small particles could be due to the splitting of bigger particles during the measurements [McFarquhar et al., 2007] and thus calls into question the previous results, the aim of this study is only to test the Lagrangian and isentropic approach in the simulation of the occurrence of such cirrus clouds. For that purpose, a small fall speed is chosen for the baseline simulations and then the influence of this parameter on the cirrus cloud occurrence will be tested in section 4.3.

[21] Water vapor mixing ratio, ice mass concentration and liquid water mass concentration are advected like the PV in the MIMOSA $-\mathrm{H}_{2} \mathrm{O}$ model without any relaxation and the microphysical module is applied every $6 \mathrm{~h}$. Since diabatic processes like convection or radiative effects are not taken into account in the model, simulations on short periods are performed to minimize potential induced effects. In fact, simulations must be long enough to allow the formation of filaments from the initialization field and short enough to allow neglecting the effects of diabatic processes. In their quantification of the isentropic air mass transport across the dynamical tropopause by small-scale filaments using contour advection technique, Dethof et al. [2000] show that the annual mass fluxes do not strongly depend on the duration of the calculations for length between 4 and 7 days.

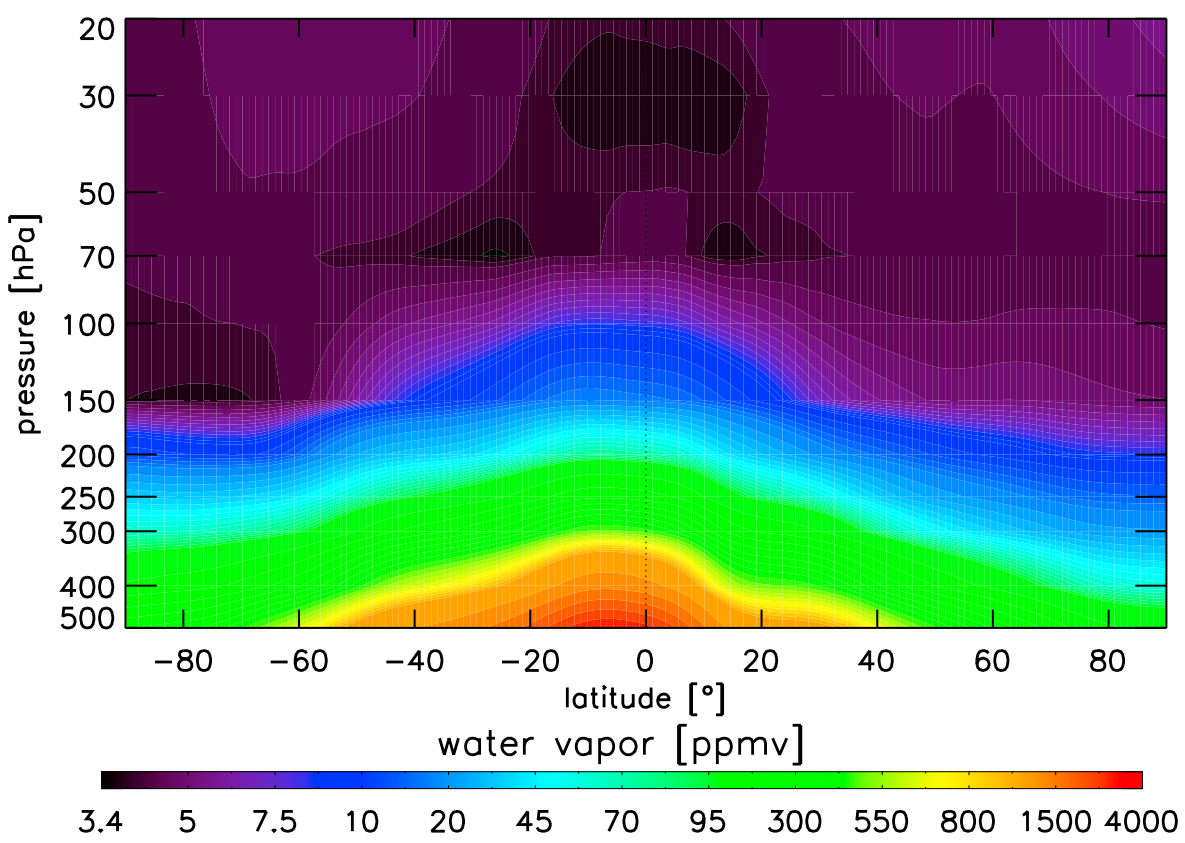

Figure 7. January climatology of the water vapor mixing ratios field function of the latitude and pressure. 
And thus Dethof et al. [2000] indicate that time scales of 4-5 days are necessary for the development of features associated with irreversible transport but allow also considering the atmosphere to be isentropic, at least by neglecting the radiative effects. In addition, convection occurs less frequently in winter at midlatitudes and seems not affect this case as it could be seen on the 3-D back trajectories in Figure 5 and on the geostationary satellite imagery.

\subsubsection{Initialization of the Water Vapor Field}

[22] The main difficulty of water vapor modeling is the initialization of the water vapor field in the model since the water vapor field is essentially unrelated to the thermal field on broad scales in the subtropical upper troposphere. Until now, the quality ( $\sim 25 \%$ for AIRS and MLS for example) as well as the vertical and spatial resolution of the water vapor measurements from space $(\sim 1-4 \mathrm{~km}$ and $\sim 200-400 \mathrm{~km}$, respectively, depending on instruments) are not enough to allow their direct assimilation in the models [Montoux et al., 2009]. To compensate for this problem the model is initialized with a climatology, giving monthly and zonally averaged water vapor mixing ratios varying with latitude and pressure (Figure 7). This climatology is built from HALOE V19, MLS V104 and ECMWF ERA-40 (T159L60) water vapor data. The HALOE data used cover the period from 11 October 1991 until 26 March 2004. Those of MLS cover the period from 19 September 1991 until 22 April 1993, and those of ECMWF cover the period from 1 January 1991 until 31 August 2002. MLS and HALOE data are combined together for pressures less than $70 \mathrm{hPa}$, and ECMWF data are used for pressure levels below $150 \mathrm{hPa}$. For the intermediate $\left(\mathrm{P}_{\mathrm{m}}\right)$ pressure levels between $70 \mathrm{hPa}\left(\mathrm{P}_{1}\right)$ and $150 \mathrm{hPa}\left(\mathrm{P}_{2}\right)$, a progressive linking is made between the two data sets with the formulation

$$
\begin{aligned}
\mathrm{H}_{2} \mathrm{O}_{P_{m}}= & \cos ^{2}\left(\frac{\pi\left(P_{m}-P_{1}\right)}{2\left(P_{2}-P_{1}\right)}\right) \times \mathrm{H}_{2} \mathrm{O}_{P_{1}} \\
& +\left(1-\cos ^{2}\left(\frac{\pi\left(P_{m}-P_{1}\right)}{2\left(P_{2}-P_{1}\right)}\right)\right) \times \mathrm{H} 2 \mathrm{O}_{P_{2}} .
\end{aligned}
$$

To avoid too much interpolation, the pressure levels chosen are the same as those of the ECMWF fields used by the model.

\section{Modeling of the Case Study}

[23] As mentioned earlier (section 3.2.1) the duration of the simulations are kept as short as possible to minimize the influence of the diabatic effects. To determine the minimal time needed, a 10 day PV simulation is made from 9 to 19 January 2006. The air mass located above OHP on 18 January 2006 at 1800 UTC and between 328 and $355 \mathrm{~K}$ passes through a latitude minimum on 15 January 2006 at $0000 \mathrm{UTC}$ varying between $20^{\circ} \mathrm{N}$ and $30^{\circ} \mathrm{N}$ depending on altitude. The model is thus initialized at this date, which is in agreement with the recommendations of Dethof et al. [2000]. In this section, the evaluation of the modeled water vapor field is made as well as the capability to reproduce the occurrence of the cirrus cloud observed with the lidar. The model gives also the estimated ice water content. Cirrus ice water content is important for studies of the clouds radiative impact [Larsen et al., 1998].

\subsection{Evaluation of the Modeled Water Vapor Field}

[24] To evaluate the model, simulated water vapor field are compared with the AIRS water vapor data. Thus MIMOSA- $\mathrm{H}_{2} \mathrm{O}$ data have been selected for 19 January 2006 at 0000 UTC and AIRS data have been selected the same day between 0000 and 0600 UTC. AIRS gives water vapor mixing ratio averaged inside layers of approximately $2 \mathrm{~km}$. To give comparable data, for each AIRS pressure layer, all water vapor data modeled on isentropic surfaces of pressures inside this pressure layer are averaged. The comparisons have been made for three pressure layers where MIMOSA- $\mathrm{H}_{2} \mathrm{O}$ data are available: $150-200 \mathrm{hPa}$, $200-250 \mathrm{hPa}$ and $250-300 \mathrm{hPa}$. The conclusions of the comparisons being the same for the three layers, only the water vapor fields of the $150-200 \mathrm{hPa}$ layer are represented on Figure 8.

[25] According to Figure 8b, MIMOSA- $\mathrm{H}_{2} \mathrm{O}$ seems to be able to qualitatively reproduce the atmospheric structures observed by AIRS in Figure 8a. For example, like AIRS, MIMOSA- $\mathrm{H}_{2} \mathrm{O}$ indicates dry areas at the west of Morocco and at the southeast of Greenland. On the other hand, wet areas are seen above North Africa and West Atlantic Ocean. However, quantitatively, there are some differences. Globally, MIMOSA $-\mathrm{H}_{2} \mathrm{O}$ gives higher mixing ratios than AIRS while AIRS is already wetter than MLS for v4 [Read et al., 2007] and than most of the other instruments, at least in the tropics for v5 [Montoux et al., 2009]. MIMOSA- $\mathrm{H}_{2} \mathrm{O}$ indicates more water vapor compared to AIRS by a factor of $50 \%$. Because the correct averaging kernels indicators of the vertical resolution of the AIRS are quite variable and were not available in the v5 data version, they have not been taken into account in the comparison with the model fields and could explain part of this systematic difference. The limited sensitivity of AIRS at pressures less than $300 \mathrm{hPa}$ (and especially at pressures less than $200 \mathrm{hPa}$ ) because of the influence of the water content from underlying layers could also bias the comparison. Tests where the initial climatological values were arbitrarily decreased by a factor of 2 decreased the wet bias in MIMOSA- $\mathrm{H}_{2} \mathrm{O}$ in comparison to AIRS but did not eliminate it $(\sim 20 \%)$. These biases were not a uniform offset. Indeed, air masses with AIRS water vapor mixing ratios smaller than 10 ppmv between 150 and $300 \mathrm{hPa}$, are always subsaturated and thus dividing the climatology by 2 decreases the modeled water vapor mixing ratios by 2 . Air masses with AIRS water vapor mixing ratios greater than $10 \mathrm{ppmv}$ between 150 and $300 \mathrm{hPa}$ are mostly saturated or supersaturated and thus the simulated water vapor mixing ratios depend mainly on the supersaturation threshold chosen. The influence of the supersaturation threshold will be studied in more details in the section 4.4. Although part of the difference between AIRS and MIMOSA- $\mathrm{H}_{2} \mathrm{O}$ could be due to the AIRS data characteristics or to the methodology used, one can also suggest the presence of an intrinsic wet bias in the MIMOSA $-\mathrm{H}_{2} \mathrm{O}$ model which needs to be further investigated with other observations such as airborne measurements from Measurements of OZone and water vapor by in-service AIrbus airCraft (MOZAIC) [Helten et al., 1999]. 


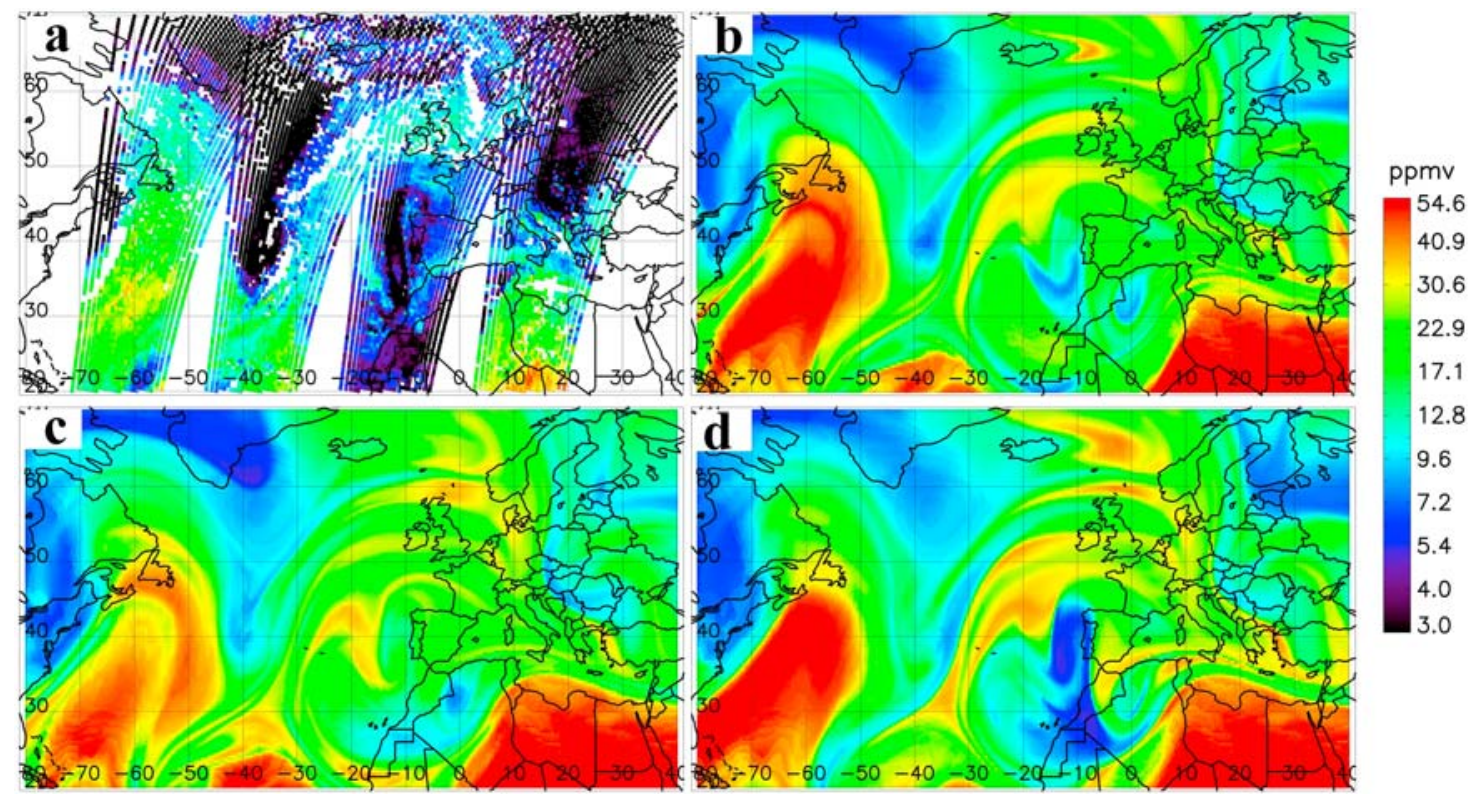

Figure 8. Water vapor mixing ratios (a) measured by AIRS on 19 January 2006 from 0000 to 0600 UTC and (b, c, and d) modeled by MIMOSA- $\mathrm{H}_{2} \mathrm{O}$ the same day at 0000 UTC in the $150-200$ pressure layer above the Atlantic Ocean. Initialization on 15 January 2006 at 0000 UTC (Figure 8b), on 14 January 2006 at 0000 UTC (Figure 8c) and on 16 January 2006 at 0000 UTC (Figure 8d). White zones are missing data for MIMOSA- $\mathrm{H}_{2} \mathrm{O}$ and AIRS or data of less reliability for AIRS.

[26] The influence of the date of initialization in the model is also tested. Initializations 1 day before and 1 day after 15 January 2006 at 0000 UTC are made and modeled water vapor mixing ratios are presented for 19 January 2006 at 0000 UTC on Figures 8c and 8d, respectively. Generally, the same structures are observed at the same localizations but the intensity of the structures changes. For example, above Greenland, the structure is drier for the initialization on 14 January 2006 and thus the wet bias compared to AIRS is less important. Around the African west coast, the structure is drier for the initialization on 16 January 2006, which is in better agreement with the AIRS observations. These results show the importance of the date of initialization on the results of the modeling. One possible reason is the different time scales of the advection mechanisms and the lack of knowledge about the time and space scales of the diffusion processes which smooth the observed structures. This issue is added to the fact that the climatology used in input combined with synoptic-scale dynamics could not resolve all the atmospheric variability observed.

\subsection{Evaluation of the Modeled Cirrus Cloud}

[27] The probable wet bias of the model affects the simulated ice water content in case of an overestimated water vapor mixing ratios just above the saturation level. The cirrus observed by lidar at OHP in the night of 18 to 19 January 2006 has a strong spatial and temporal variability as shown in Figure 9a. Figure 9a depicts the $532 \mathrm{~nm}$ lidar scattering ratio function of altitude between 11 and $15 \mathrm{~km}$ by periods of around $90 \mathrm{~min}$. At the beginning of the night, before 2218 UTC, the cirrus cloud stands between 12 and $14 \mathrm{~km}$ while after $2218 \mathrm{UTC}$, the cirrus cloud stands between 12 and $13.6 \mathrm{~km}$. It is impossible to distinguish from lidar observation alone if its variability in altitude is due to spatial variability or to temporal variability induced, for example, by sedimentation of ice particles. Indeed, to have an acceptable signal-to-noise ratio, longer integration time ( $\sim 90 \mathrm{~min})$ of the lidar measurements than the 5 min basic integration time is necessary and prevents from distinguishing fall streaks in the low-resolution time evolution of the scattering ratio. At the pressure of the cirrus cloud, around $150 \mathrm{hPa}$, winds above France provided by the ECMWF analysis are oriented northnorthwest on 18 January 2006 at 1800 UTC with an intensity on the order of $100 \mathrm{~km} / \mathrm{h}$. As a result, the lidar has sounded an air mass of approximately $800 \mathrm{~km}$ along an axis Gent, Belgium $\left(51.02^{\circ} \mathrm{N} ; 3.42^{\circ} \mathrm{E}\right) / \mathrm{OHP}$. Figure $9 \mathrm{~b}$ shows the modeled ice water content for 18 January 2006 at 1800 UTC for different locations along this axis and $300 \mathrm{~km}$ around the OHP. The model reproduces this cirrus cloud at approximately the same altitude where it is observed, between 12.5 $(\sim 335 \mathrm{~K})$ and $14.5 \mathrm{~km}(\sim 360 \mathrm{~K})$ for most of the profiles. For the northwest profile, ice particles are simulated down to $11.13 \mathrm{~km}(\sim 328 \mathrm{~K})$. For all profiles, their modeled extension above $14 \mathrm{~km}(\sim 350 \mathrm{~K})$, while no signature is observed by the lidar, can be supported by two explanations. First, the simulated water vapor mixing ratios between 14 and $14.5 \mathrm{~km}$ are slightly higher than the ice saturation mixing ratios. Thus, if we take into account the possible wet bias of the model highlighted earlier, we can make the assumption that the air mass is subsaturated at this altitude and hence does not produce any cloud. Second, near the tropopause, it is commonly found that radiosoundings at midlatitudes show the same shape with a decrease of temperature with altitude in the troposphere followed by a sharp increase of temperature on approximately $1 \mathrm{~km}$ and a lesser decrease of temperature above. Figure 10 illustrates this with three examples of temperature profiles recorded between 11 and $16 \mathrm{~km}$, on 18 January 2006 at 1200 UTC by three meteorological stations: 

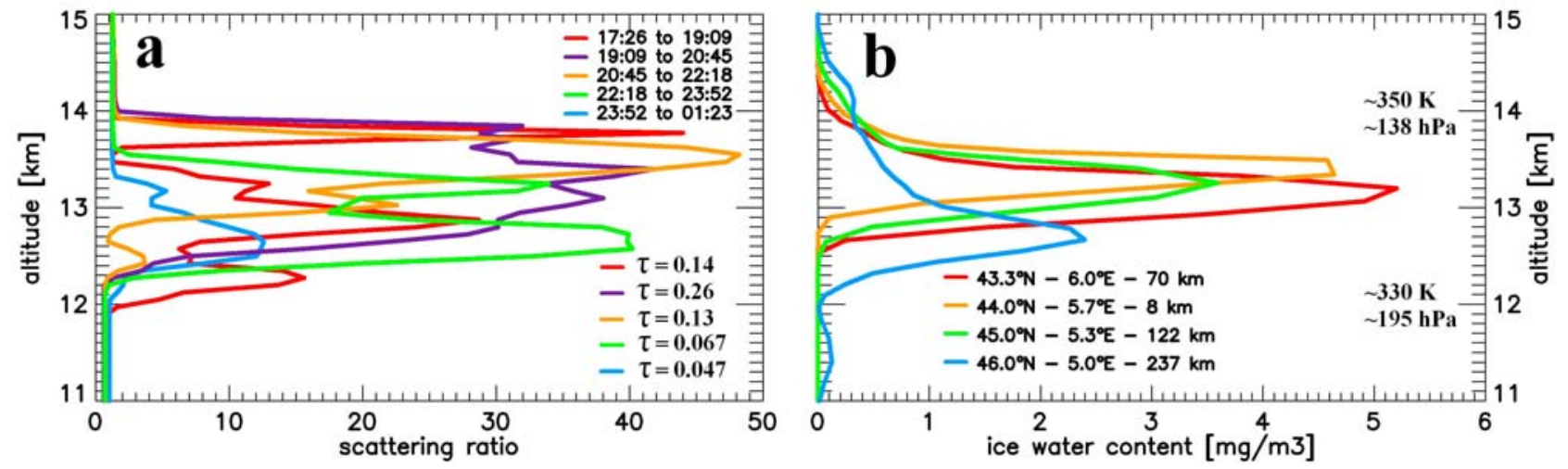

Figure 9. (a) The $532 \mathrm{~nm}$ lidar scattering ratio between 11 and $15 \mathrm{~km}$ measured at the Observatory of Haute-Provence in the night between 18 and 19 January 2006. The different colors are scattering ratios integrated on different periods of around $90 \mathrm{~min}$ all along the night with indication of the associated cloud optical depths $\tau$. (b) Modeled ice water content on 18 January 2006 at 1800 UTC in the same altitude range. The different colors are for different locations near the Observatory of Haute-Provence with the distances to the Observatory mentioned in the legend.

Nottingham and Herstmonceux in England and Trappes in France (see locations in Figure 2). The corresponding temperature profiles extracted from the ECMWF analyses and interpolated at the model resolution are also shown in Figure 10. It clearly shows that the temperature profiles available as input for the model are not able to reproduce the features seen in the radiosoundings. In particular, the underestimation of the temperature by $3 \mathrm{~K}$ in average around $14-15 \mathrm{~km}$ is enough to decrease the ice water vapor saturation mixing ratio and explains the presence of ice at these levels with low ice water content $\left(<0.5 \mathrm{mg} / \mathrm{m}^{3}\right)$. In contrast, around $12-13 \mathrm{~km}$, the temperature in the model is overestimated compared to the radiosounding that can induce an underestimation of the ice water content formed and probably explains the absence of ice in the model below $12.5 \mathrm{~km}$ (except for the northwest profile of Figure 9b). In a future version of the model, it would be interesting to test higher vertical resolution ECMWF temperature profiles (T799L91) to see if these features are resolved.

[28] Figure 11 shows the time evolution of the altitude, temperature, pressure and ice water content along back trajectories initialized at $44^{\circ} \mathrm{N}$ and $5.67^{\circ} \mathrm{E}$ between $336 \mathrm{~K}$ and $348 \mathrm{~K}$ each $1 \mathrm{~K}$ between 15 January 2006 at $0600 \mathrm{UTC}$ and 18 January 2006 at 1800 UTC. The time evolution of these parameters is reconstructed from the MIMOSA- $\mathrm{H}_{2} \mathrm{O}$ fields by extracting the values along the trajectories shown for some levels in Figure 2. The air mass observed at the altitude of the cirrus cloud on 18 January 2006 at 1800 UTC has in fact a different origin depending on the altitude. Between $336 \mathrm{~K}$ and $340 \mathrm{~K}$, the air mass is originating from the midlatitudes between $47^{\circ} \mathrm{N}$ and $50^{\circ} \mathrm{N}$ while between $342 \mathrm{~K}$ and $348 \mathrm{~K}$, the air mass is originating from the subtropics between $24^{\circ} \mathrm{N}$ and $38^{\circ} \mathrm{N}$ as seen for some levels in Figure 2. These differences in location induced a difference in the temperatures and pressures experienced (Figure 11). From 16 January 2006, the air mass experiences quite the same winds and thus the same temperature and pressure evolutions on the whole altitude range (between $336 \mathrm{~K}$ and $348 \mathrm{~K}$ ). From this date, the altitude of each isentropic surface increases and the temperature and pressure decrease of around $1 \mathrm{~km}, 10 \mathrm{~K}$ and $30 \mathrm{hPa}$, respectively, during the last two days. Thus the cirrus cloud is progressively created in the model with the decrease of the temperature until the date of the observation (Figure 11). This could explain that, in this case, the radiative processes are not necessary to maintain the cirrus cloud since the supersaturation is always reached even at the observation time and thus ice continue to be formed in the model. In addition, the fallout of the ice particles during the last $18 \mathrm{~h}(\sim 260 \mathrm{~m})$ during which most of the ice is formed, is largely compensated by the increasing altitude of the isentropic surfaces $(\sim 500 \mathrm{~m})$.

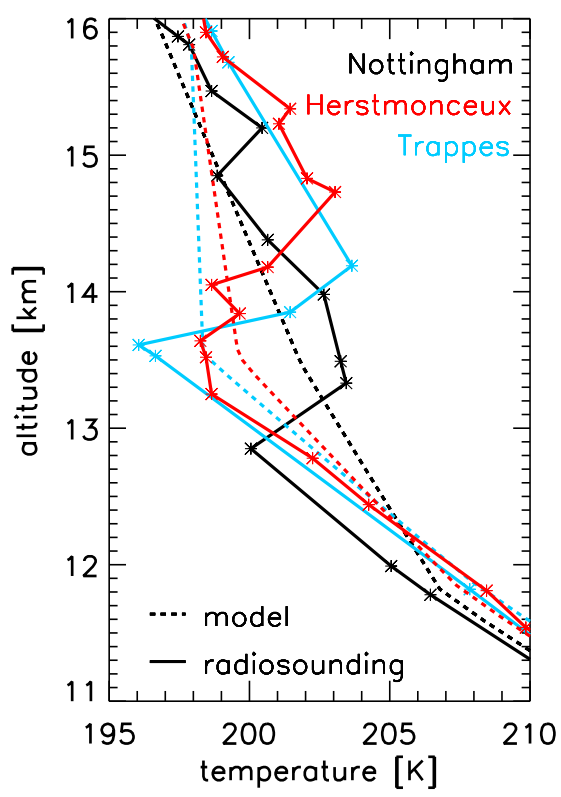

Figure 10. Radiosounding temperature profiles (solid lines) on 18 January 2006 at 1200 UTC and ECMWF temperature profiles interpolated at the MIMOSA model resolution (dotted lines) on 18 January 2006 at 1200 UTC between 11 and $16 \mathrm{~km}$. Black is Nottingham station, red is Herstmonceux station, and blue is Trappes station. Around $14-15 \mathrm{~km}$, there is model underestimation. Around 12-13 $\mathrm{km}$, there is model overestimation. 


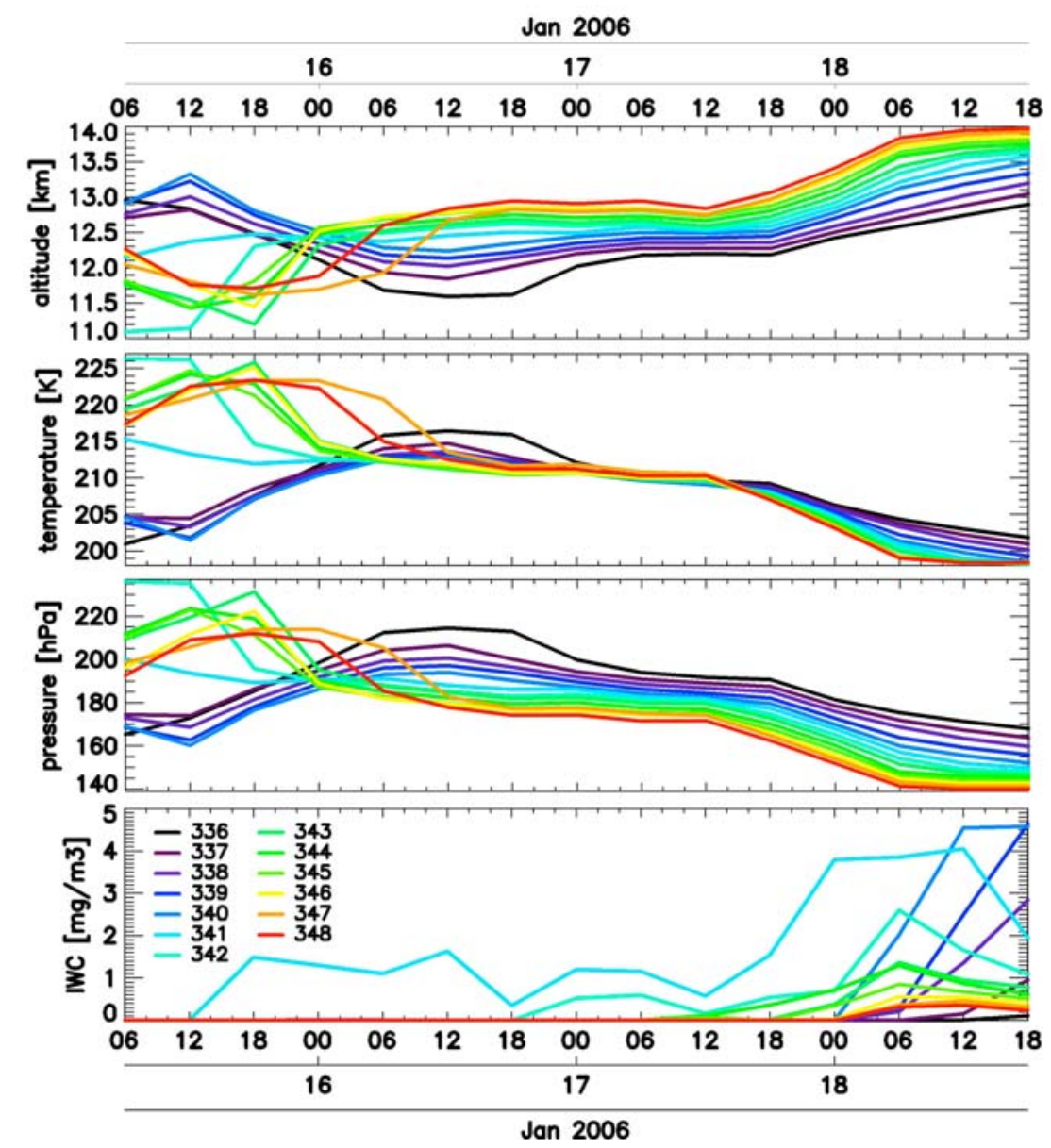

Figure 11. (top to bottom) Evolution of the altitude, temperature, pressure, and ice water content of the air mass in the MIMOSA- $\mathrm{H}_{2} \mathrm{O}$ model between 15 January 2006 at 0600 UTC and 18 January 2006 at 1800 UTC obtained from back trajectories initialized at $44^{\circ} \mathrm{N}$ and $5.67^{\circ} \mathrm{E}$ for the isentropic levels between $336 \mathrm{~K}$ and $348 \mathrm{~K}$ at $1 \mathrm{~K}$ resolution.

This lifting could reach up to $2.2 \mathrm{~cm} / \mathrm{s}$ during the 0000 0600 UTC time period on 18 January 2006.

\subsection{Influence of the Fall Speed}

[29] In Figure 9, modeled ice water content has been only shown between 11 and $15 \mathrm{~km}$ but below $11 \mathrm{~km}$, MIMOSA$\mathrm{H}_{2} \mathrm{O}$ simulates an ice cloud that is not seen on the lidar measurements. This ice cloud has greater ice water content than the cirrus cloud around $12-14 \mathrm{~km}$ studied in section 4.2 with more than $200 \mathrm{mg} / \mathrm{m}^{3}$ around $9 \mathrm{~km}$. The aim of this section is twofold. First, we want to test the influence of the fall speed on the altitude of the simulated cirrus cloud observed between $12 \mathrm{~km}$ and $14 \mathrm{~km}$ and on its ice water content. But this could not be done without considering the cloud present in the model below $11 \mathrm{~km}$. To deduce the contribution of this low cloud, two different types of simulations are made: one type (named 1) for all the isentropic levels between $320 \mathrm{~K}(\sim 8.4 \mathrm{~km})$ and $430 \mathrm{~K}$ $(\sim 18.6 \mathrm{~km})$ as previously and the second type (named 2$)$ for only the isentropic levels between $320 \mathrm{~K}$ and $329 \mathrm{~K}$ $(\sim 11.8 \mathrm{~km})$. Then for each type of simulation, different simulations are made by changing the values of the fall speed in the model by steps from 0 to $30 \mathrm{~cm} / \mathrm{s}$. To study, the influence of the fall speed on the high cirrus cloud observed at OHP only, the difference between the type 1 and type 2 simulations is made and presented in section 4.3.1 and Figure 12. Second, we want understand the presence of the low ice cloud in the model, not observed at OHP. Even if it is very probable that this cloud could be explained by the wet bias in the simulated water vapor field, considering that no in situ data are available to determine if all the ice water

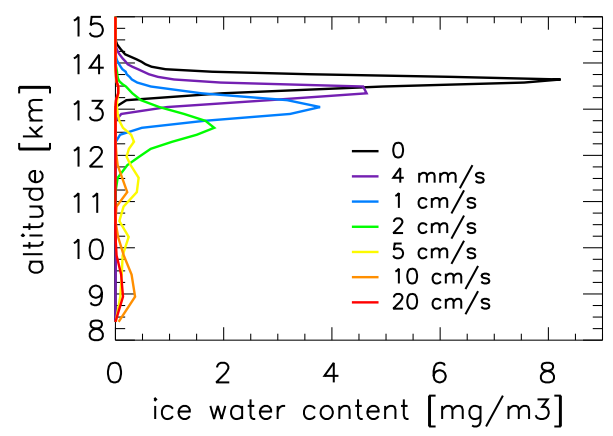

Figure 12. Variation of the modeled cirrus cloud altitude and ice water content according to the fall speed (color codes) fixed in the model at $44^{\circ} \mathrm{N} / 5.67^{\circ} \mathrm{E}$ on 18 January 2006 at 1800 UTC between 8 and $15 \mathrm{~km}$. 


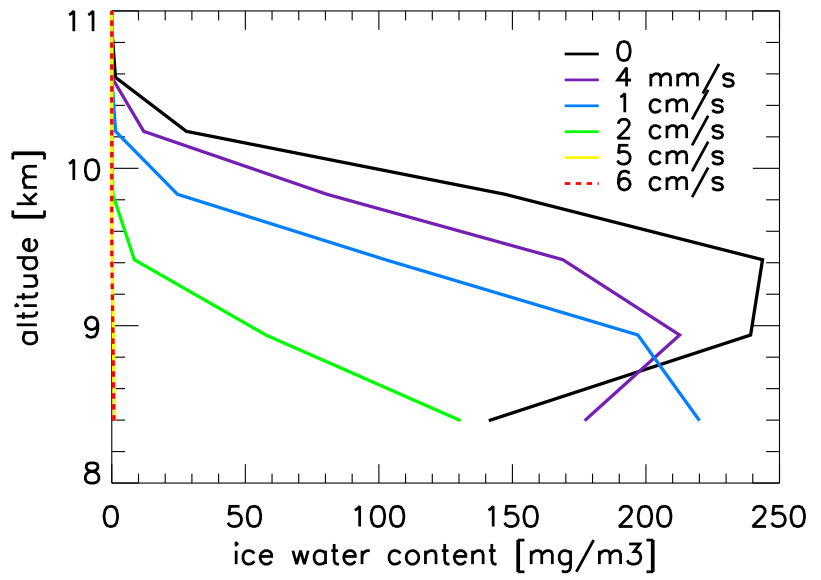

Figure 13. Variation of the modeled ice water content according to the fall speed (color codes) fixed in the model at $44^{\circ} \mathrm{N} / 5.67^{\circ} \mathrm{E}$ on 18 January 2006 at 1800 UTC between 8 and $11 \mathrm{~km}$.

content could be explained by the wet bias, other probable explanations are tested. Notably, we want to know if this cloud could be explained by a too small fall speed in the model. This is made in section 4.3.2 and Figure 13 by using only the type 2 simulations excluding the contribution of the high cirrus cloud. Other explanation about the presence of this low cloud in the model is also provided in this section. 4.3.1. Comparisons With Cirrus Observed by Lidar

[30] Figure 12 shows the altitude and ice water content of the cirrus cloud for different values of the fall speed in the model for the OHP location $44^{\circ} \mathrm{N} / 5.67^{\circ} \mathrm{E}$ on 18 January 2006 at 1800 UTC. As seen on this figure, the greater the fall speed, the lower the cirrus cloud altitude and the weaker its ice water content maximum. Without sedimentation of the ice particles, the cirrus cloud is modeled between 13.1 and $14.4 \mathrm{~km}$ that is $400 \mathrm{~m}$ above the altitude observed by the lidar at OHP. For fall speeds between $4 \mathrm{~mm} / \mathrm{s}$ and $1.5 \mathrm{~cm} / \mathrm{s}$, the altitude and thickness of the cirrus cloud observed at OHP are correctly reproduced by the model mainly if one considers the differences between the model temperatures and the measurements, as reported in section 4.2 and highlighted on Figure 10. The maximum of ice water content inside the cirrus cloud is then between approximately 2.6 and $4.6 \mathrm{mg} /$ $\mathrm{m}^{3}$. For fall speed greater than $2 \mathrm{~cm} / \mathrm{s}$, the altitude of the modeled cirrus cloud top decreases while its thickness increases and reaches a maximum greater than $4.5 \mathrm{~km}$ for a fall speed of $5 \mathrm{~cm} / \mathrm{s}$. The maximum of ice water content inside the cirrus cloud is then less than $1.8 \mathrm{mg} / \mathrm{m}^{3}$. These values are on the same order of magnitude than the measurements made by Heymsfield [2003] at midlatitudes where cirrus clouds with ice water content of $1 \mathrm{mg} / \mathrm{m}^{3}$ have median massweighted terminal velocities between 10 and $20 \mathrm{~cm} / \mathrm{s}$. Below $8.4 \mathrm{~km}$, the air mass being subsaturated, all the ice particles that sediment are evaporated. Finally, for a fall speed greater than $30 \mathrm{~cm} / \mathrm{s}$ (not shown), the cirrus cloud totally disappears in the model.

4.3.2. Ice Cloud Occurrence Below $11 \mathrm{~km}$ in the Model

[31] Now, the presence of ice in the model below $11 \mathrm{~km}$ is studied separately with the type 2 simulations. The influence of the fall speed on the ice water content is presented in Figure 13. Above OHP, with a fall speed of $4 \mathrm{~mm} / \mathrm{s}$, the ice water content increases below $10.2 \mathrm{~km}(\sim 324 \mathrm{~K})$ up to a maximum at $8.9 \mathrm{~km}(\sim 321 \mathrm{~K})$ of $213 \mathrm{mg} / \mathrm{m}^{3}$ and decreases below (Figure 13). As the fall speed increases, the ice water content decreases on the whole altitude range and thus only $0.4 \mathrm{mg} / \mathrm{m}^{3}$ stay at $321 \mathrm{~K}$ for a fall speed of $6 \mathrm{~cm} / \mathrm{s}$. This ice cloud completely disappears for fall speeds greater than $11 \mathrm{~cm} / \mathrm{s}$ (not shown) above $320 \mathrm{~K}(\sim 8.4 \mathrm{~km}$, i.e., the lower level of the model). Additional comparisons with ice saturation water vapor profiles from the Nîmes radiosoundings measurements of relative humidity, temperature and pressure performed on 18 January 2006 at 1200 UTC and 19 January at 0000 UTC allow us to check if the cloud disappears also below $320 \mathrm{~K}$. Below $9.2 \mathrm{~km}$, the pressure being greater than $300 \mathrm{hPa}$, the relative humidity measurements used to calculate the water vapor mixing ratios can be considered as reliable [Suortti et al., 2008]. Around $8.5 \mathrm{~km}$, the air mass is 300-350 ppmv less than the saturation, hence allowing evaporating all the ice particles which could have fallen out.

[32] This sensitivity study shows that a fall speed of $11 \mathrm{~cm} / \mathrm{s}$ (not shown) is sufficient for a complete disappearance of the ice cloud below $11 \mathrm{~km}$ but is too large to reproduce the cirrus cloud seen by lidar between 12 and $14 \mathrm{~km}$. However, the ice water content decreases by a factor of 50 from 9 to $13 \mathrm{~km}$ from around 200 to $4 \mathrm{mg} / \mathrm{m}^{3}$. Several studies such as those of Heymsfield and Donner [1990], Heymsfield [2003] and Deng and Mace [2008] have shown that the fall speed (or the median mass-weighted terminal velocity) decreases with the decrease of the ice water content. For example, Heymsfield [2003] has shown that at midlatitudes, for ice water content around $100 \mathrm{mg} / \mathrm{m}^{3}$, the median mass-weighted terminal velocity is around $100 \mathrm{~cm} / \mathrm{s}$, while for ice water content of $1 \mathrm{mg} / \mathrm{m}^{3}$, it varies between 10 and $20 \mathrm{~cm} / \mathrm{s}$. However, the cirrus clouds studied in these studies are often warmer or at lower altitudes than the case analyzed here $(\sim 13 \mathrm{~km})$. For example, the cirrus clouds studied by Heymsfield [1977, 2003] have a top altitude at temperatures warmer than $-65^{\circ} \mathrm{C}$ while the temperatures of the top and base of the cirrus cloud considered here are $-72^{\circ} \mathrm{C}$ and $-66^{\circ} \mathrm{C}$ respectively. The fall speed around $13 \mathrm{~km}$ can thus reasonably be expected to be smaller than $10-20 \mathrm{~cm} / \mathrm{s}$ in accordance with the result given in section 4.3.1. The number of ice particles, their shape, their size and the total ice water content vary with the temperature and thus modify the fall speed [Heymsfield and Iaquinta, 2000]. For the temperature encountered around $9 \mathrm{~km}\left(-45^{\circ} \mathrm{C}\right)$, a fall speed greater than $11 \mathrm{~cm} / \mathrm{s}$, providing the disappearance of the ice cloud, is thus in agreement with the measurements $(20$ to $90 \mathrm{~cm} / \mathrm{s})$ made by Heymsfield [2003] at these temperatures. In addition, inside a same cirrus cloud, particles of different sizes are observed with generally a broad size distribution like in the measurements shown for example in the paper of Lin et al. [1998]. The larger ice crystals, generally in smaller concentration, fall faster and have the greater ice water content while the smaller ice crystals, generally in greater concentration, fall slower and stay above the larger ice crystals [Heymsfield and Iaquinta, 2000]. Thus, using a single-valued fall speed does not allow reproduction of these features, less distinct for the subvisible cirrus clouds. In some studies, the use of a sizeand shape-dependent ice crystals terminal fall speed allows, however, the mimicking of this behavior [Haag and Kärcher, 2004; Mitchell et al., 2008]. 
Table 1. Variation of the Cloud Characteristics According to the Supersaturation Threshold Fixed in the Model at $44^{\circ} \mathrm{N} / 5.67^{\circ} \mathrm{E}$ on 18 January 2006 at 1800 UTC

\begin{tabular}{llllll}
\hline & \multicolumn{5}{c}{ Supersaturation Threshold } \\
\cline { 2 - 6 } & $100 \%$ & $130 \%$ & $150 \%$ & $100 \%$ & $130 \%$ \\
\hline Fall speed $(4 \mathrm{~mm} / \mathrm{s})$ & no & no & no & yes & yes \\
Cloud top altitude $(\mathrm{km})$ & 14.61 & 14.40 & 14.08 & 14.61 & 14.40 \\
Cloud base altitude $(\mathrm{km})$ & 12.45 & 13.19 & 13.19 & 11.20 & 12.75 \\
Thickness $(\mathrm{km})$ & 2.16 & 1.21 & 0.89 & 3.41 & 14.03 \\
Maximal ice water content $\left(\mathrm{mg} / \mathrm{m}^{3}\right)$ & 8.76 & 8.22 & 7.81 & 4.67 & 1.65 \\
Altitude of the maximal ice water content $(\mathrm{km})$ & 13.64 & 13.64 & 13.64 & 13.34 & 1.28 \\
Ice water path $\left(\mathrm{g} / \mathrm{m}^{2}\right)$ & 3.46 & 2.83 & 2.51 & 2.68 & 13.34 \\
\end{tabular}

[33] We also investigated the hypothesis of a real atmospheric temperature warmer than that of the ECMWF analysis used in the model that can explain the presence of ice particles below $11 \mathrm{~km}$ in the model. Comparisons between temperature profiles from radiosounding and from the ECMWF analysis (interpolated at the MIMOSA model resolution) have been performed for five meteorological stations close to the ice cloud location on 18 January 2006 at 1200 UTC (not shown). These five stations, localized on Figure 2, are Nottingham and Herstmonceux in England, and Trappes, Lyon and Nîmes in France. Between 8 and $11 \mathrm{~km}$, the mean difference between radiosounding and analysis temperatures (pressures) is $-0.06 \pm 0.34 \mathrm{~K}(-0.42 \pm$ $0.16 \mathrm{hPa}$ ) without the Lyon profile. These differences are small and thus too weak to explain the presence of ice at these altitudes in the model. On the other hand, the Lyon radiosounding temperatures and pressures are warmer and greater than those of the ECMWF analysis from $3.06 \pm 0.37 \mathrm{~K}$ and $1.54 \pm 0.38 \mathrm{hPa}$, respectively. Even if the Lyon radiosounding indicates a warmer area of small extent above the east part of France, only part of the ice cloud might be explained by the difference in pressure and temperature. This part of the ice cloud $(\sim 40 \%)$ represents the difference between the saturation water vapor mixing ratio calculated with the radiosounding pressure and temperature and the model water vapor mixing ratio which could evaporate during a time step of $6 \mathrm{~h}$ with the time constant $\tau_{\mathrm{v}}$. In conclusion, it is most probable that the presence of ice particles in the model around $9 \mathrm{~km}$ is due to the wet bias in the simulated water vapor field. But in the possibility that all the ice water content simulated could not be explained by the wet bias, the variation of the fall speed with altitude would seem to be a better probable explanation than the difference between the analyzed and measured temperature and pressure data.

\subsection{Influence of the Supersaturation Threshold}

[34] Measurements acquired by several instruments have shown the presence of supersaturation even at midlatitudes. For example, humidity measurements, whose accuracy is estimated to be of $7 \%(2 \sigma)$, recorded by a frost-point hygrometer during the INCA project at Prestwich in Scotland $\left(55.51^{\circ} \mathrm{N} / 4.58^{\circ} \mathrm{W}\right)$ in March-April 2000 have shown supersaturations $(>105 \%)$ inside cirrus clouds with occurrence of $31 \%$ [Ovarlez et al., 2002]. Lower supersaturations $(<105-110 \%)$ occur more frequently for temperatures warmer than $-40^{\circ} \mathrm{C}$ than for temperatures colder than $-40^{\circ} \mathrm{C}$ while it is the contrary for higher supersaturations $(>105-110 \%$ up to $160 \%$ ). The measured supersaturations can reach $170 \%$ inside cirrus clouds. Those measurements have also shown that even in clear sky conditions, supersaturations up to $130 \%$ have been observed $9 \%$ of the time. Similarly, the MOZAIC data indicate a frequency of supersaturation at midlatitudes of $11.2 \pm 5.6 \%$ at $200 \mathrm{hPa}$ and $15.2 \pm 7.0 \%$ at $250 \mathrm{hPa}$ with a maximum of $33 \%$ at $10^{\circ} \mathrm{W}$ of Brittany [Gierens et al., 2000]. In addition to the need to reach supersaturations higher than $30 \%$ to form cirrus clouds at temperatures lower than $-55^{\circ} \mathrm{C}$ [Heymsfield et al., 1998], Khvorostyanov and Sassen [1998] emphasized the possibility of having a residual supersaturation even after formation of the first ice crystals.

[35] However, the aim of this section is not to give the supersaturation threshold required to form the cirrus cloud with the characteristics observed at OHP but is rather to test the influence of supersaturation with values in accordance with the results cited above on the pattern of the cirrus cloud and its ice water content. For this purpose, the same simulation has been made for three thresholds: $100 \%$ (no supersaturation), $130 \%$ (used for previous simulations) and $150 \%$. The characteristics of the cirrus cloud simulated at OHP between around $12 \mathrm{~km}$ and $14 \mathrm{~km}$ are summarized in Table 1 . Since the temperatures at the altitude of the cloud are very cold $(<205 \mathrm{~K})$, the saturation threshold is not a decisive factor in the occurrence of the cirrus cloud in the model. However, the results show that the supersaturation threshold has a strong influence on the cloud thickness: changing the threshold from $100 \%$ to $150 \%$ leads to division of the cloud thickness by a factor of around 2.5. On the other hand, the altitude of the maximum of ice water content inside the cirrus cloud remains approximately the same $(\sim 13.61 \mathrm{~km})$. Finally the supersaturation threshold has a lesser influence on the ice water content, the ice water path being divided by a factor 1.4 when raising the threshold from $100 \%$ to $150 \%$. The derived ice content, around $2-3 \mathrm{~g} / \mathrm{m}^{2}$, is in agreement with the ones obtained by Wang and Sassen [2002] for a cloud of $2 \mathrm{~km}$ thickness and a midcloud temperature around $-70^{\circ} \mathrm{C}$. In summary, the supersaturation threshold seems to impact strongly the vertical and horizontal extension of the cirrus cloud and slightly the ice water path. According to the altitude and extent of the cirrus cloud and its temperature, the parasol effect (reflection of the sun light back into space) and the greenhouse effect of the cirrus cloud vary [Liou, 1986]. Thus, the supersaturation threshold should impact the radiative properties of the cloud and deserve to be further studied in the future.

\section{Summary and Discussion}

[36] The detailed study of a case of an optically thin cirrus cloud observed by lidar at OHP around the tropopause has allowed examining the influence of synoptic-scale forcing 
on cirrus cloud formation over France and more precisely the influence of the polar jet stream. The cirrus cloud observed during the night from 18 to 19 January 2006 was located between 12 and $14 \mathrm{~km}(\sim 136-190 \mathrm{hPa} / 328-$ $355 \mathrm{~K}$ ), straddling the tropopause. Our back trajectory simulations show that the higher part of the air mass observed comes from the wet subtropics while the lower part comes from the midlatitudes. Both are advected by the Azores anticyclone, experience cold temperatures ( $205 \mathrm{~K}$ ) above the North Atlantic Ocean and flow eastward along the anticyclonic flank of the polar jet stream.

[37] The possibility of modeling this type of cirrus cloud with an isentropic model has been evaluated. For this purpose, new developments have been made in the global, high-resolution, semi-Lagrangian and isentropic model MIMOSA that relies on the advection of potential vorticity leading to a new extension of the model called MIMOSA$\mathrm{H}_{2} \mathrm{O}$. These developments allow taking into account the three phases of water and the interactions between them. The implementation of a supersaturation threshold is specified in the model, inducing a delay in the conversion of water vapor or supercooled water into ice. The sedimentation of the ice particles is considered using a constant fall speed. Finally, the initialization of the water vapor field is performed by a monthly zonal mean climatology constructed from the HALOE, MLS and ECMWF water vapor data.

[38] The results show that this model is able to reproduce the atmospheric water vapor structures observed on a global scale by AIRS, with, however, a wet bias of around $50 \%$. This bias needs to be further investigated in the future with other data sets such as MOZAIC in situ aircraft data [Luo et $a l ., 2008]$. If it is confirmed that the bias is due to an overestimation of water vapor by MIMOSA- $\mathrm{H}_{2} \mathrm{O}$, this could induce an overestimation of the cirrus cloud occurrence and of the modeled ice water contents inside the cirrus clouds. The model reproduces the cirrus cloud altitude and thickness for fall speeds around $1 \mathrm{~cm} / \mathrm{s}$ and supersaturation threshold of $130 \%$. However, it must be kept in mind that the wet bias in the model and, to a greater extent, the resolution of the ECMWF temperature analysis around the tropopause can also impact the modeled cirrus cloud altitude and thickness. Considering the fall speed, a sensitivity study highlighted the need for a better parameterization to avoid the formation of unrealistic cirrus clouds before using the model for other cases. As already shown in several studies, to correctly reproduce the cirrus cloud observed by lidar between 12 and $14 \mathrm{~km}$ with no clouds below, the fall speed must be greater at warmer temperatures and greater ice water contents [Heymsfield and Donner, 1990; Heymsfield and Iaquinta, 2000; Heymsfield, 2003; Deng and Mace, 2008]. The relationship between fall speed, temperature and ice water content proposed by Deng and Mace [2008] needs to be tested, and evaluation with Doppler measurements could be useful. The modeled ice water content is weak, around $3-4 \mathrm{mg} / \mathrm{m}^{3}$, and might be overestimated by the wet bias of the model. It is at present difficult to plan an evaluation of the modeled ice water content by in situ or remote measurements. Indeed, Davis et al. [2007] have shown, for example, that some disagreements exist between three instruments measuring ice water contents smaller than $10 \mathrm{mg} / \mathrm{m}^{3}$. At global scale, the precision of the EOS-MLS of $1.8 \mathrm{mg} / \mathrm{m}^{3}$ and $3 \mathrm{mg} / \mathrm{m}^{3}$ at $147 \mathrm{hPa}$ and $215 \mathrm{hPa}$, respectively [ $\mathrm{Li}$ et al., 2005], is inadequate to detect this type of cirrus cloud with very small ice water content. Considering the very low temperatures encountered by the air mass in this study, the cirrus cloud is reproduced whatever the value of the supersaturation threshold, at least up to $150 \%$. On the other hand, the supersaturation threshold impacts strongly the vertical and horizontal extension of the cirrus cloud and more slightly the ice water path.

[39] Among 92 observations of cirrus clouds acquired in 2000 by the OHP lidar, 31 observations $(\sim 35 \%)$ have quite the same characteristics of the cirrus cloud studied [Keckhut et al., 2006]. This class of cirrus clouds represents an occurrence frequency of around $17 \%$ considering that the global cirrus occurrence frequency, based on 384 nights of lidar measurements performed on the period 1997-1999, is of nearly 50\% [Goldfarb et al., 2001]. Although intrusion of subtropical air above France seems to occur at the same frequency ( 1 day in 5), at least in January 2006 as could be seen on the MIMOSA PV maps, depending on the temperature encountered, intrusion of subtropical air is not necessarily synonymous with cirrus cloud occurrence, and thin tropopause cirrus may also be related to cumulonimbus clouds anvils advected to midlatitudes [Garrett et al., 2004]. A complementary study would thus be necessary to address the question of how much this process is responsible for the cirrus occurrence above France. Because the polar jet stream plays also an important role in the formation of the cirrus cloud studied, it might be interesting to further investigate other cases and test the influence of its strength, which decreases during boreal summer, on the occurrence of cirrus clouds.

[40] Acknowledgments. This study was supported by the European Commission within the SCOUT-O3 project (contract 505390-GOCECT2004). HALOE data were provided by NASA Langley Research Centre (NASA-LaRC) and NASA Langley Radiation and Aerosols Branch. Those of AIRS and MLS were acquired as part of the NASA's Earth-Sun System Division and archived and distributed by the Goddard Earth Sciences (GES) Data and Information Services Center (DISC) Distributed Active Archive Center (DAAC). The radiosoundings used in this study are from the RAOB database available at http://www-frd.fsl.noaa.gov/mab/raob/. Cathy Boonne is thanked for the extraction and conversion of the ECMWF data, Bernd Kärcher is thanked for his help in providing references used in this study to develop the model, and Jean-Pierre Cammas is thanked for his advice. The OHP team is thanked for the lidar data acquisition, as well as the French funding agencies: INSU-CNRS, CNES, and ADEME. Hélène Brogniez is deeply indebted to R.T. Pierrehumbert for providing us his model and would like to acknowledge R. Roca for fruitful discussions around its use in this study. Constructive comments and suggestions for improvements from the two anonymous referees are gratefully acknowledged.

\section{References}

Aumann, H. H., et al. (2003), AIRS/AMSU/HSB on the Aqua mission: Design, science objectives, data products, and processing systems, IEEE Trans. Geosci. Remote Sens., 41, 253-264, doi:10.1109/TGRS.2002. 808356.

Baran, A. J., and P. N. Francis (2004), On the radiative properties of cirrus cloud at solar and thermal wavelengths: A test of model consistency using high-resolution airborne radiance measurements, $Q$. J. R. Meteorol. Soc., 130(598), 763-778, doi:10.1256/qj.03.151.

Bithell, M., and L. J. Gray (1997), Contour lengthening rates near the tropopause, Geophys. Res. Lett., 24(22), 2721-2724, doi:10.1029/ 97GL02954.

Boehm, M. T., J. Verlinde, and T. P. Ackerman (1999), On the maintenance of high tropical cirrus, J. Geophys. Res., 104(D20), 24,423-24,433, doi:10.1029/1999JD900798. 
Comstock, J. M., R.-F. Lin, D. O’C. Starr, and P. Yang (2008), Understanding ice supersaturation, particle growth, and number concentration in cirrus clouds, J. Geophys. Res., 113, D23211, doi:10.1029/ 2008JD010332.

Davis, S. M., L. M. Avallone, E. M. Weinstock, C. H. Twohy, J. B. Smith and G. L. Kok (2007), Comparisons of in situ measurements of cirrus cloud ice water content, J. Geophys. Res., 112, D10212, doi:10.1029/ 2006JD008214

Deng, M., and G. G. Mace (2008), Cirrus cloud microphysical properties and air motion statistics using cloud radar Doppler moments: Water content, particle size, and sedimentation relationships, Geophys. Res. Lett., 35, L17808, doi:10.1029/2008GL035054.

Dethof, A., A. O'Neill, and J. Slingo (2000), Quantification of the isentropic mass transport across the dynamical tropopause, J. Geophys. Res. 105(D10), 12,279-12,293, doi:10.1029/2000JD900127.

Divakarla, M. G., C. D. Barnet, M. D. Goldberg, L. M. McMillin, E. Maddy, W. Wolf, L. Zhou, and X. Liu (2006), Validation of Atmospheric Infrared Sounder temperature and water vapor retrievals with matched radiosonde measurements and forecasts, J. Geophys. Res., 111, D09S15, doi:10.1029/2005JD006116

Dowling, D. R., and L. F. Radke (1990), A summary of the physica properties of cirrus clouds, J. Appl. Meteorol., 29, 970-978, doi:10.1175/1520-0450(1990)029<0970:ASOTPP $>2.0 . C O ; 2$

Durry, G., and A. Hauchecorne (2005), Evidence for long-lived polar vortex air in the mid-latitude summer stratosphere from in situ laser diode $\mathrm{CH}_{4}$ and $\mathrm{H}_{2} \mathrm{O}$ measurements, Atmos. Chem. Phys., 5, 1467-1472.

Durry, G., A. Hauchecorne, J. Ovarlez, H. Ovarlez, I. Pouchet, V. Zeninari, and B. Parvitte (2002), In situ measurement of $\mathrm{H}_{2} \mathrm{O}$ and $\mathrm{CH}_{4}$ with telecommunication laser diodes in the lower stratosphere: Dehydration and indication of a tropical air intrusion at mid-latitudes, J. Atmos. Chem., 43, 175-194, doi:10.1023/A:1020674208207.

Edwards, J. M., S. Havemann, J.-C. Thelen, and A. J. Baran (2007), A new parametrization for the radiative properties of ice crystals: Comparison with existing schemes and impact in a GCM, Atmos. Res., 83, 19-35, doi:10.1016/j.atmosres.2006.03.002.

Fusina, F., P. Spichtinger, and U. Lohmann (2007), Impact of ice supersaturated regions and thin cirrus on radiation in the midlatitudes, J. Geophys. Res., 112, D24S14, doi:10.1029/2007JD008449.

Garrett, T. J., A. J. Heymsfield, M. J. McGill, B. A. Ridley, D. G Baumgardener, T. P. Bui, and C. R. Webster (2004), Convective generation of cirrus near the tropopause, J. Geophys. Res., 109, D21203, doi:10.1029/ 2004JD004952.

Gettelman, A., W. J. Randel, F. Wu, and S. T. Massie (2002), Transport of water vapor in the tropical tropopause layer, Geophys. Res. Lett., 29(1), 1009, doi:10.1029/2001GL013818

Gierens, K., U. Schumann, M. Helten, H. Smit, and P.-H. Wang (2000), Icesupersaturated regions and subvisible cirrus in the northern midlatitude upper troposphere, J. Geophys. Res., 105(D18), 22,743-22,753, doi:10.1029/2000JD900341.

Godin, S., M. Marchand, and A. Hauchecorne (2002), Influence of the Arctic polar vortex erosion on the lower stratospheric ozone amounts at Haute-Provence Observatory $\left(44^{\circ} \mathrm{N}, 6^{\circ} \mathrm{E}\right)$, J. Geophys. Res., 107(D20), 8272, doi:10.1029/2001JD000516.

Goldfarb, L., P. Keckhut, M.-L. Chanin, and A. Hauchecorne (2001), Cirrus climatological results from lidar measurements at OHP $\left(44^{\circ} \mathrm{N}, 6^{\circ} \mathrm{E}\right)$, Geophys. Res. Lett., 28(9), 1687-1690, doi:10.1029/2000GL012701.

Haag, W., and B. Kärcher (2004), The impact of aerosols and gravity waves on cirrus clouds at midlatitudes, J. Geophys. Res., 109, D12202, doi:10.1029/2004JD004579.

Hauchecorne, A., S. Godin, M. Marchand, B. Hesse, and C. Souprayen (2002), Quantification of the transport of chemical constituents from the polar vortex to midlatitudes in the lower stratosphere using the high-resolution advection model MIMOSA and effective diffusivity, J. Geophys. Res., 107(D20), 8289, doi:10.1029/2001JD000491.

Haynes, P., and E. Shuckburgh (2000), Effective diffusivity as a diagnostic of atmospheric transport: 2. Troposphere and lower stratosphere, J. Geophys. Res., 105(D18), 22,795-22,810, doi:10.1029/2000JD900092.

Heese, B., S. Godin, and A. Hauchecorne (2001), Forecast and simulation of stratospheric ozone filaments: A validation of a high-resolution PV advection model by airborne ozone lidar measurements in winter 1998 1999, J. Geophys. Res., 106(D17), 20,011-20,024, doi:10.1029/ 2000JD900818.

Helten, M., H. G. J. Smit, D. Kley, J. Ovarlez, H. Schlager, R. Baumann, U. Schumann, P. Nedelec, and A. Marenco (1999), In-flight comparison of MOZAIC and POLINAT water vapor measurements, J. Geophys. Res., 104(D21), 26,087-26,096, doi:10.1029/1999JD900315.

Heymsfield, A. J. (1977), Precipitation development in Stratiform ice clouds: A microphysical and dynamical study, J. Atmos. Sci., 34, $367-$ 381, doi:10.1175/1520-0469(1977)034<0367:PDISIC>2.0.CO;2.
Heymsfield, A. J. (2003), Properties of tropical and midlatitude ice cloud particle ensembles. Part II: Applications for mesoscale and climate models, J. Atmos. Sci., 60, 2592-2611, doi:10.1175/1520-0469(2003)060< 2592:POTAMI>2.0.CO;2.

Heymsfield, A. J., and L. J. Donner (1990), A scheme for parameterizing ice-cloud water content in general circulation models, J. Atmos. Sci. 47(15), 1865-1877, doi:10.1175/1520-0469(1990)047<1865:ASFPIC $>$ 2.0.CO;2

Heymsfield, A. J., and J. Iaquinta (2000), Cirrus crystal terminal velocities, J. Atmos. Sci., 57, 916-938, doi:10.1175/1520-0469(2000)057< 0916:CCTV>2.0.CO;2.

Heymsfield, A. J., L. M. Miloshevich, and C. Twohy (1998), Uppertropospheric relative humidity observations and implications for cirrus ice nucleation, Geophys. Res. Lett., 25(9), 1343-1346, doi:10.1029/ 98GL01089.

Holton, J. R. (1992), An Introduction to Dynamic Meteorology, 3rd ed., 511 pp., Academic Press, San Diego, Calif

Holton, J. R., and A. Gettelman (2001), Horizontal transport and dehydration in the stratosphere, Geophys. Res. Lett., 28(14), 2799-2802, doi:10.1029/2001GL013148.

Jensen, E. J., L. Pfister, T.-P. Bui, A. Weinheimer, E. Weinstock, J. Smith, J. Pittmann, D. Baumgardner, and M. J. McGill (2005), Formation of a tropopause cirrus layer observed over Florida during CRYSTAL-FACE, J. Geophys. Res., 110, D03208, doi:10.1029/2004JD004671.

Kärcher, B. (2003), Simulating gas-aerosol-cirrus interactions: Processoriented microphysical model and applications, Atmos. Chem. Phys., 3, $1645-1664$.

Keckhut, P., A. Hauchecorne, S. Bekki, A. Colette, C. David, and J. Jumelet (2005), Indications of thin cirrus clouds in the stratosphere at mid-latitudes, Atmos. Chem. Phys., 5, 3407-3414.

Keckhut, P., F. Borchi, S. Bekki, A. Hauchecorne, and M. SiLaouina (2006), Cirrus classification at midlatitude from systematic lidar observations, J. Appl. Meteorol. Climatol., 45,249-258, doi:10.1175/JAM2348.1.

Khvorostyanov, V., and K. Sassen (1998), Cirrus cloud simulation using explicit microphysics and radiation. Part II: Microphysics, vapor and ice mass budgets, and optical and radiative properties, J. Atmos. Sci., 55 , 1822 - 1845, doi:10.1175/1520-0469(1998)055<1822:CCSUEM $>2.0$. $\mathrm{CO} \cdot 2$

Larsen, H., J.-F. Gayet, G. Febvre, H. Chepfer, and G. Brogniez (1998), Measurement errors in cirrus cloud microphysical properties, Ann. Geophys., 16, 266-276, doi:10.1007/s00585-998-0266-8.

Legras, B., B. Joseph, and F. Lefèvre (2003), Vertical diffusivity in the lower stratosphere from Lagrangian back-trajectory reconstructions of ozone profiles, J. Geophys. Res., 108(D18), 4562, doi:10.1029/ 2002JD003045.

Li, J.-L., et al. (2005), Comparisons of EOS MLS cloud ice measurements with ECMWF analyses and GCM simulations: Initial results, Geophys. Res. Lett., 32, L18710, doi:10.1029/2005GL023788.

Lin, H., K. J. Noone, J. Ström, and A. J. Heymsfield (1998), Small ice crystals clouds: A model study and comparison with in situ observations, J. Atmos. Sci., 55, 1928-1939, doi:10.1175/1520-0469(1998)055< 1928: $\mathrm{SICICC}>2.0 . \mathrm{CO} ; 2$

Lin, R.-F., D. O. Starr, J. Reichardt, and P. J. DeMott (2005), Nucleation in synoptically forced cirrostratus, J. Geophys. Res., 110, D08208, doi:10.1029/2004JD005362.

Liou, K.-N. (1986), Influence of cirrus clouds on weather and climate processes: A global perspective, Mon. Weather Rev., 114, 1167-1199, doi:10.1175/1520-0493(1986)114<1167:IOCCOW>2.0.CO;2.

Luo, Z., D. Kley, R. H. Johnson, and H. Smit (2008), Ten years of measurements of tropical upper-tropospheric water vapor by MOZAIC. Part II: Assessing the ECMWF humidity analysis, J. Clim., 21, 1449-1466, doi:10.1175/2007JCLI1887.1.

Mace, G. G., S. Benson, and S. Kato (2006), Cloud radiative forcing at the Atmospheric Radiation Measurement Program Climate Research Facility: 2. Vertical redistribution of radiant energy by clouds, J. Geophys. Res., 111, D11S91, doi:10.1029/2005JD005922.

McFarquhar, G. M., J. Um, M. Freer, D. Baumgardner, G. L. Kok, and G. Mace (2007), Importance of small ice crystals to cirrus properties: Observations from the Tropical Warm Pool International Cloud Experiment (TWP-ICE), Geophys. Res. Lett., 34, L13803, doi:10.1029/ 2007GL029865

Mitchell, D. L., P. Rasch, D. Ivanova, G. McFarquhar, and T. Nousiainen (2008), Impact of small ice crystal assumptions on ice sedimentation rates in cirrus clouds and GCM simulations, Geophys. Res. Lett., 35, L09806, doi:10.1029/2008GL033552.

Montoux, N., et al. (2009), Evaluation of balloon and satellite water vapour measurements in the southern tropical and subtropical UTLS during the HIBISCUS campaign, Atmos. Chem. Phys., 9, 5299-5319.

Ovarlez, J., J.-F. Gayet, K. Gierens, J. Ström, H. Ovarlez, F. Auriol, R. Busen, and U. Schumann (2002), Water vapour measurements inside cirrus clouds 
in Northern and Southern hemispheres during INCA, Geophys. Res. Lett., 29(16), 1813, doi:10.1029/2001GL014440.

Pierrehumbert, R. T. (1998), Lateral mixing as a source of subtropical water vapour, Geophys. Res. Lett., 25(2), 151-154, doi:10.1029/97GL03563.

Pierrehumbert, R. T., and R. Roca (1998), Evidence for control of Atlantic subtropical humidity by large scale advection, Geophys. Res. Lett. 25(24), 4537-4540, doi:10.1029/1998GL900203.

Rao, T. N., S. Kirkwood, J. Arvelius, P. von der Gathen, and R. Kivi (2003), Climatology of UTLS ozone and the ratio of ozone and potential vorticity over northern Europe, J. Geophys. Res., 108(D22), 4703, doi:10.1029/2003JD003860.

Read, W. G., et al. (2007), Aura Microwave Limb Sounder upper tropospheric and lower stratospheric $\mathrm{H}_{2} \mathrm{O}$ and relative humidity with respect to ice validation, J. Geophys. Res., 112, D24S35, doi:10.1029/ 2007JD008752.

Reichardt, J., S. Reichardt, R.-F. Lin, M. Hess, T. J. McGee, and D.O. Starr (2008), Optical-microphysical cirrus model, J. Geophys. Res., 113, D22201, doi:10.1029/2008JD010071.

Sassen, K., and B. S. Cho (1992), Subvisual-thin cirrus lidar dataset for satellite verification and climatological research, J. Appl. Meteorol., 31 , 1275 - 1285, doi:10.1175/1520-0450(1992)031<1275:STCLDF $>$ 2.0.CO;2.

Sassen, K., D. O’C. Starr, and T. Uttal (1989), Mesoscale and microscale structure of cirrus clouds: Three case studies, J. Atmos. Sci., 46, $371-$ 396, doi:10.1175/1520-0469(1989)046<0371:MAMSOC>2.0.CO;2.

Semane, N., H. Bencherif, B. Morel, A. Hauchecorne, and R. D. Diab (2006), An unusual stratospheric ozone decrease in the Southern Hemisphere subtropics linked to isentropic air-mass transport as observed over Irene $\left(25.5^{\circ} \mathrm{S}, 28.1^{\circ} \mathrm{E}\right)$ in mid-May 2002, Atmos. Chem. Phys., 6 , $1927-1936$

Stephens, G. L., S.-C. Tsay, P. W. Stackhouse Jr., and P. J. Flatau (1990), The relevance of the microphysical and radiative properties of cirrus clouds to climate and climatic feedback, J. Atmos. Sci., 47, $1742-$ 1753, doi:10.1175/1520-0469(1990)047<1742:TROTMA >2.0.CO;2.

Stohl, A., O. Cooper, and P. James (2004), A cautionary note on the use of Meteorological analysis fields for quantifying atmospheric mixing,
J. Atmos. Sci., 61, 1446-1453, doi:10.1175/1520-0469(2004)061< 1446:ACNOTU>2.0.CO;2.

Ström, J., et al. (2003), Cirrus cloud occurrence as function of ambient relative humidity: A comparison of observations obtained during the INCA experiment, Atmos. Chem. Phys., 3, 1807-1816.

Suortti, T. M., et al. (2008), Tropospheric comparisons of Vaisala radiosondes and balloon-borne frost-point and Lyman- $\alpha$ hygrometers during the LAUTLOS-WAVVAP experiment, J. Atmos. Oceanic Technol., 25(2), 149-166, doi:10.1175/2007JTECHA887.1.

Tobin, D. C., H. E. Revercomb, R. O. Knuteson, B. M. Lesht, L. L. Strow, S. E. Hannon, W. F. Feltz, L. A. Moy, E. J. Fetzer, and T. S. Cress (2006), Atmospheric Radiation Measurement site atmospheric state best estimates for Atmospheric Infrared Sounder temperature and water vapor retrieval validation, J. Geophys. Res., 111, D09S14, doi:10.1029/ 2005JD006103.

Wang, Z., and K. Sassen (2002), Cirrus cloud microphysical property retrieval using lidar and radar measurements. Part II: Midlatitude cirrus microphysical and radiative properties, J. Atmos. Sci., 59, 2291-2302, doi:10.1175/1520-0469(2002)059<2291:CCMPRU>2.0.CO;2.

Waugh, D. W., et al. (1997), Mixing of polar vortex air into middle latitudes as revealed by tracer-tracer scatterplots, J. Geophys. Res., 102(D11), 13,119-13,134, doi:10.1029/96JD03715.

Wylie, D. P., W. P. Menzel, H. M. Woolf, and K. I. Strabala (1994), Four years of global cirrus cloud statistics using HIRS, J. Clim., 7, 19721986, doi:10.1175/1520-0442(1994)007<1972:FYOGCC>2.0.CO;2.

Zhang, M. H., et al. (2005), Comparing clouds and their seasonal variations in 10 atmospheric general circulation models with satellite measurements, J. Geophys. Res., 110, D15S02, doi:10.1029/2004JD005021.

H. Brogniez, C. David, A. Hauchecorne, J. Jumelet, P. Keckhut, and N. Montoux, Laboratoire Atmosphères Milieux Observations Spatiales, UPMC-B102, CNRS, Tour 45/46-4ième étage, 4 Place Jussieu, F-75252 Paris CEDEX 5, France. (nadege.montoux@latmos.ipsl.fr) 